\title{
Value of Control in Family Firms: Evidence from Mergers and Acquisitions
}

\author{
Nihat Aktas* \\ WHU - Otto Beisheim School of Management, Germany \\ Santo Centineo \\ WHU - Otto Beisheim School of Management, Germany \\ Ettore Croci \\ Universita' Cattolica del Sacro Cuore, Italy
}

This article studies European acquisitions in the period 1990-2013 to examine the relationship between family ownership and the propensity to undertake diversifying acquisitions. We show that family firms, especially those highly leveraged, tend to make more cross-industry acquisitions as this allows the owners to effectively diversify their wealth without selling their shares. Our results also indicate that family firms that value control high (i.e., family firms with high leverage) appear not to diversify at the detriment of minority shareholders. (JEL: G34)

Keywords: family firms; leverage; control motives; acquisitions

Article history: Received: 16 October 2015, Received in final revised form: 10 February 2016, Accepted: 10 May 2016, Available online: 30 August 2016

\section{Introduction}

Families are the most common type of controlling blockholder around

\footnotetext{
* Corresponding author at: Chair of Mergers and Acquisitions, WHU - Otto Beisheim School of Management, Burgplatz 2, 56179 Vallendar, Germany. Email address: nihat.aktas@whu.edu. We thank Panayiotis Andreou (the Editor), Burcin Yurtoglu, and an anonymous referee for helpful comments and suggestions.
}

(Multinational Finance Journal, 2016, vol. 20, no. 2, pp. 85-126)

(C) Multinational Finance Society, a nonprofit corporation. All rights reserved. DOI: $10.17578 / 20-2-1$ 
the world, even when we consider publicly listed firms (La Porta, Lopez-de-Silanes and Shleifer, 1999; Faccio and Lang, 2002). Despite a vast literature on the effect of family ownership on firm value and performance (see, e.g., Barontini and Caprio, 2006; Maury, 2006; Sraer and Thesmar, 2007; Andres, 2008; Franks et al., 2012 for Europe; Anderson and Reeb, 2003a; Villalonga and Amit, 2006; Miller et al., 2007 for the United States; Claessens et al., 2002 for Asia; Lins, Volpin and Wagner, 2013 at international level), the implications of family ownership on financial choices and their effects have received limited attention (see, e.g., Anderson and Reeb, 2003b; Ellul, 2008; and Croci, Doukas and Gonenc, 2011). ${ }^{1}$

Families are blockholders known to be particularly attached to their firms, because they are often in position to extract both pecuniary and non-pecuniary private benefits of control (Barclay and Holderness, 1989; Demsetz and Lehn, 1985). They are more emotionally and financially tied to their companies and are often directly involved in managing the firm's resources. For these reasons, families are deemed to have a long-term commitment towards their own firms, which sometimes span several generations. They do not solely view their firms in terms of cash flows to be consumed but also as an asset to pass on to future generations (Becker, 1981; Casson, 1999; Chami, 1999; James, 1999; Bertrand and Schoar, 2006; Tsoutsoura, 2015). Using Bertrand and Schoar (2006) words, families provide "patient capital" to their firms, which put them in position to make decisions that maximize long-run returns. Even if families often own under-diversified portfolios because of the large investment in the family business, family firms experience less diversification than non-family firms (Anderson and Reeb, 2003b). Faccio, Marchica and Mura (2011) document that when ownership is concentrated and personal wealth is tied up in the family business, risky investments beyond the firm's range of expertise and knowledge is less likely undertaken.

Control motives of family blockholders influence financing decisions: the firm's capital structure might reflect this specific attitude toward control because control motives are directly linked to shareholding and debt structure decisions of the firm. Since families value control so highly, they are reluctant to relinquish or even reduce it by funding new investments with new equity issues (Harris and Raviv, 1988; Israel, 1991). Stulz (1988) observes that the mix of equity and debt financing is important due to its effect on the distribution of voting

1. Anderson and Reeb (2003a) and Holderness (2009) provide evidence that family firms are also diffuse in the United States. 
rights. Therefore, families may rely on debt financing to maintain ownership level and voting power. Empirical evidence supports this hypothesis: families have indeed a preference for issuing non-diluting securities (i.e. debt) to fund new investments, leading their firms to be more leveraged than non-family firm (Ellul, 2008; Croci, Doukas and Gonenc, 2011). ${ }^{2}$ This preference to rely on debt to avoid dilution could induce family firms to carry out diversifying acquisitions to stabilize the firm's cash-flows and minimize the likelihood of financial distress.

Using leverage as a proxy for the family owner's attitude toward control, we investigate and test the relationship between investment decisions and financial structures in different type of firms. The category of investment decisions chosen for this study is the acquisition activity of firms, one of the most important decisions in a company's life. Family blockholders with strong control motives might be reluctant to sell their shares and to use these cash proceeds to undertake different investment opportunities to diversify away from their business. As a result, the only means to diversify their wealth, which is for the most part tied up in the business, is the diversification of the business itself. Therefore, this study tests the propensity of carrying out cross-industry acquisition investment for family firms and non-family firms respectively, conditional on leverage. Given their commitment to the firm, both monetary and emotional, we can expect that family owners will show a higher propensity for cross-industry investments when their firms' leverage is high than non-family firms.

Our sample includes all mergers and acquisitions announced over the period 1990-2013 by European firms. We show that family firms with high leverage tend to make more diversifying acquisitions, since family blockholders do not want to sell shares and hence lose control, but at the same time would like to diversify their personal wealth which is tied up in the business (Miller, Le Breton-Miller and Lester, 2010; May, 1995). This result supports the implication of Ellul (2008) that high leverage in family firms signals strong control motives of the owners (i.e., family blockholders value control high). We also provide evidence that the cross-industry investments of family firms whose blockholders attach a high value to control are not at the expense of

2. One representative firm example for this policy of debt financing in order to avoid control dilution is the international media company Bertelsmann, a German family-owned firm since 1835. In 2001 Groupe Bruxelles Lambert (GBL) took a 25.1\% stake in Bertelsmann. Five years later Bertelsmann was issuing debt and accepting a doubling of its existing leverage ratio in order to buy back GBL's stake for $\$ 5.75$ billion (even overpaying) to prevent its public listing (The Economist, 2006). 
minority shareholders.

This paper adds to the literature devoted to the investment decisions of family firms (see, e.g., Klasa, 2007; Bauguess and Stegemoller, 2008; Sraer and Thesmar, 2007; Caprio, Croci and Del Giudice, 2011; Miller, Le Breton-Miller and Lester, 2010). The paper builds on the notion that the attitude toward control of the main shareholder shapes the firm investment policy via the firm's financing decisions. We provide evidence that family owners with high control motives, captured by the firm's leverage ratio, tend to diversify their firm through cross-industry takeovers. This finding is consistent with Miller, Le Breton-Miller and Lester (2010), in which the authors document that the propensity to make diversifying acquisitions increases with the level of family ownership. We extend Miller, Le Breton-Miller and Lester (2010) result along two dimensions: (i) we document when family owners launch more diversifying acquisitions, i.e. when they have high levels of debt; (ii) we also show that diversifying acquisitions are not detrimental to minority shareholders for levered family firms whose owners are unlikely to relinquish control.

The remaining part of this article is structured as follows. Section II is devoted to the literature review and the development of the hypotheses. Section III describes the sample and documents the data sources. Section IV presents the empirical results. Finally, Section V concludes.

\section{Literature review and hypothesis development}

\section{A. Literature review}

The economic relevance of family firms is widely discussed in the economic literature. Since Berle and Means (1932) conceptualized the modern corporation, particular attention of the finance academic community has been devoted to widely held corporations. In reality, however, only a minority of firms are actually widely held. Most of them are controlled either by families or public institutions (La Porta, Lopez-de-Silanes and Shleifer, 1999; Faccio and Lang, 2002). Alderson (2011) reports that $70 \%-80 \%$ of all businesses in Europe are owned or controlled by families. Whereas in the United Kingdom and Ireland

widely held firms are more important, family controlled firms are more 
common in Continental Europe (Faccio and Lang, 2002). ${ }^{3}$ Strong emotional ties, provision of patient capital, orientation towards sustainable growth and promotion of long-term stability are just few characteristics which are attributed to family firms (Ampenberger et al., 2009; Achleitner et al., 2010).

The relevance of family firms for the prosperity and economic development of nations is not negligible. Family firms were one of the most important sources of start-up capital and drivers of new job creation (Chrisman, Chua and Steier, 2003). Furthermore, several studies indicate that family firms achieve superior financial performance compared to non-family firms and this both in terms of operating performance and stock market performance (see, e.g., McConaughy, Matthews and Fialko, 2001; Anderson and Reeb, 2003a; Barontini and Caprio, 2006; Jaskiewicz, 2006; Villalonga and Amit, 2006; Sraer and Thesmar, 2007).

Table 1 presents the largest family firms in Europe with annual sales over $€ 25$ billion and the officially reported stakes of the families. The table shows that several famous companies are actually family-owned and characterized by large revenues and workforce.

Ownership concentration might be able to diminish agency conflicts between firm management and shareholders. This is known as the "alignment effect" in agency theory (Jensen and Meckling, 1976; Demsetz and Lehn, 1985). Firm survival is extremely important to families, especially in order to preserve their reputation as well as their legacy to future generations of the family. They are interested in maximizing long-term value, investing efficiently and passing the firm in a good shape onto next generations (Becker, 1981; Casson, 1999; Chami, 1999; James, 1999). Regarding investment decisions, family blockholders are better at scrutinizing M\&A opportunities and preventing value destroying transactions. Several articles document that family firms are indeed more careful acquirers than their non-family counterparts (see, e.g., Ben-Amar and Andre, 2006, for the Canadian market; Basu, Dimitrova and Paeglis, 2009, and Adhikari, 2013, for the US market; Sraer and Thesmar, 2007, and Bouzgarrou and Navatte, 2013, for the French market).

However, there is also a well-known dark side of family ownership:

3. This might also be explained by the findings of Franks et al. (2012) who suggest that family firms are more likely to survive in countries with less developed financial markets, weak investor protection and low M\&A activity which are prevalent in Continental Europe. 


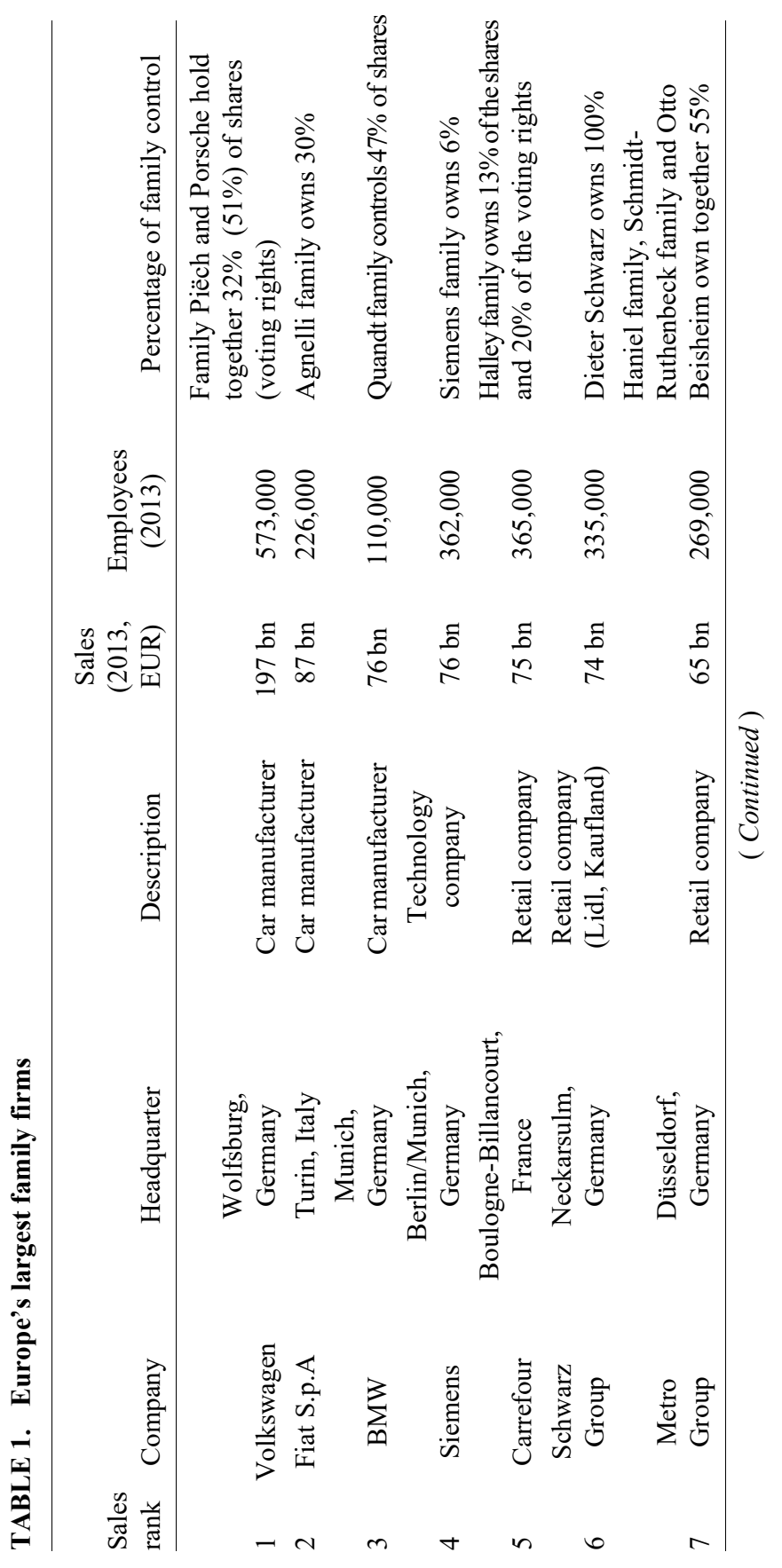




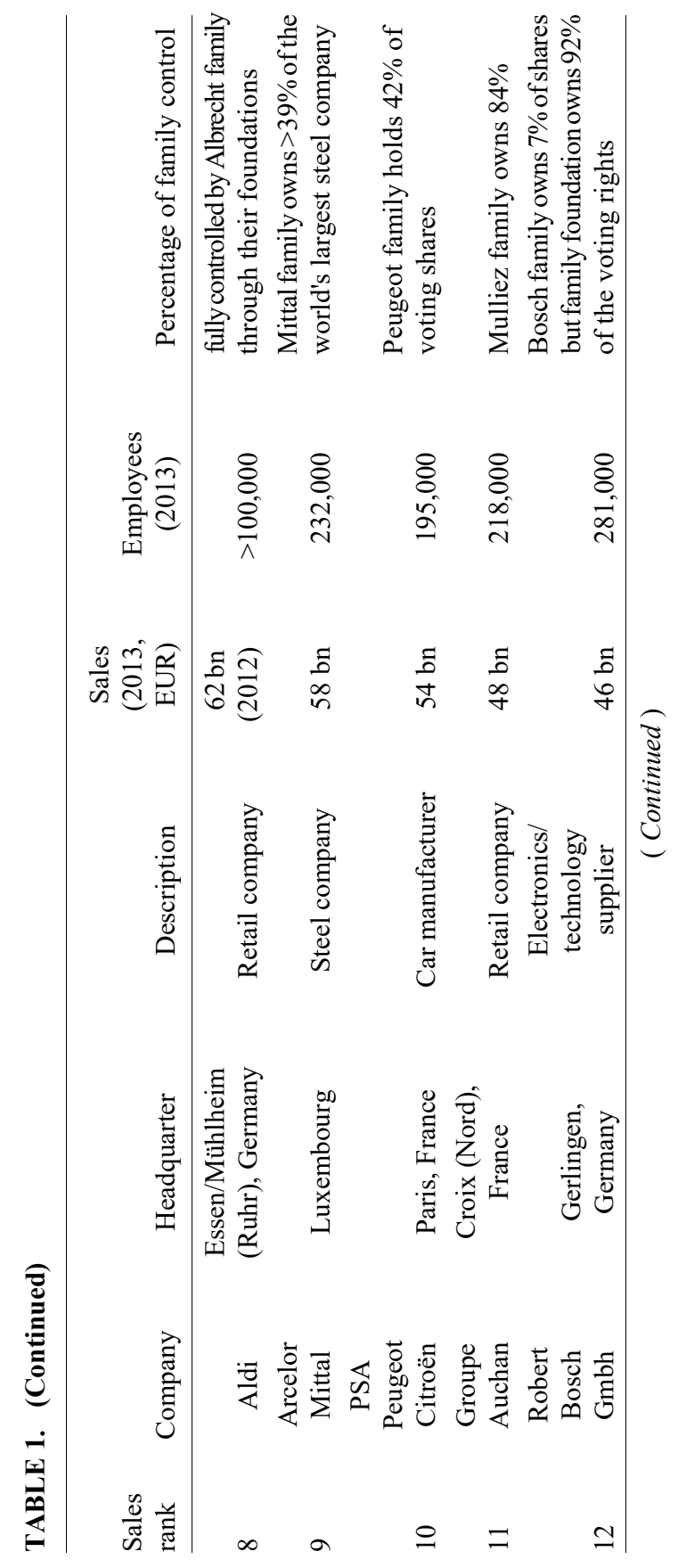




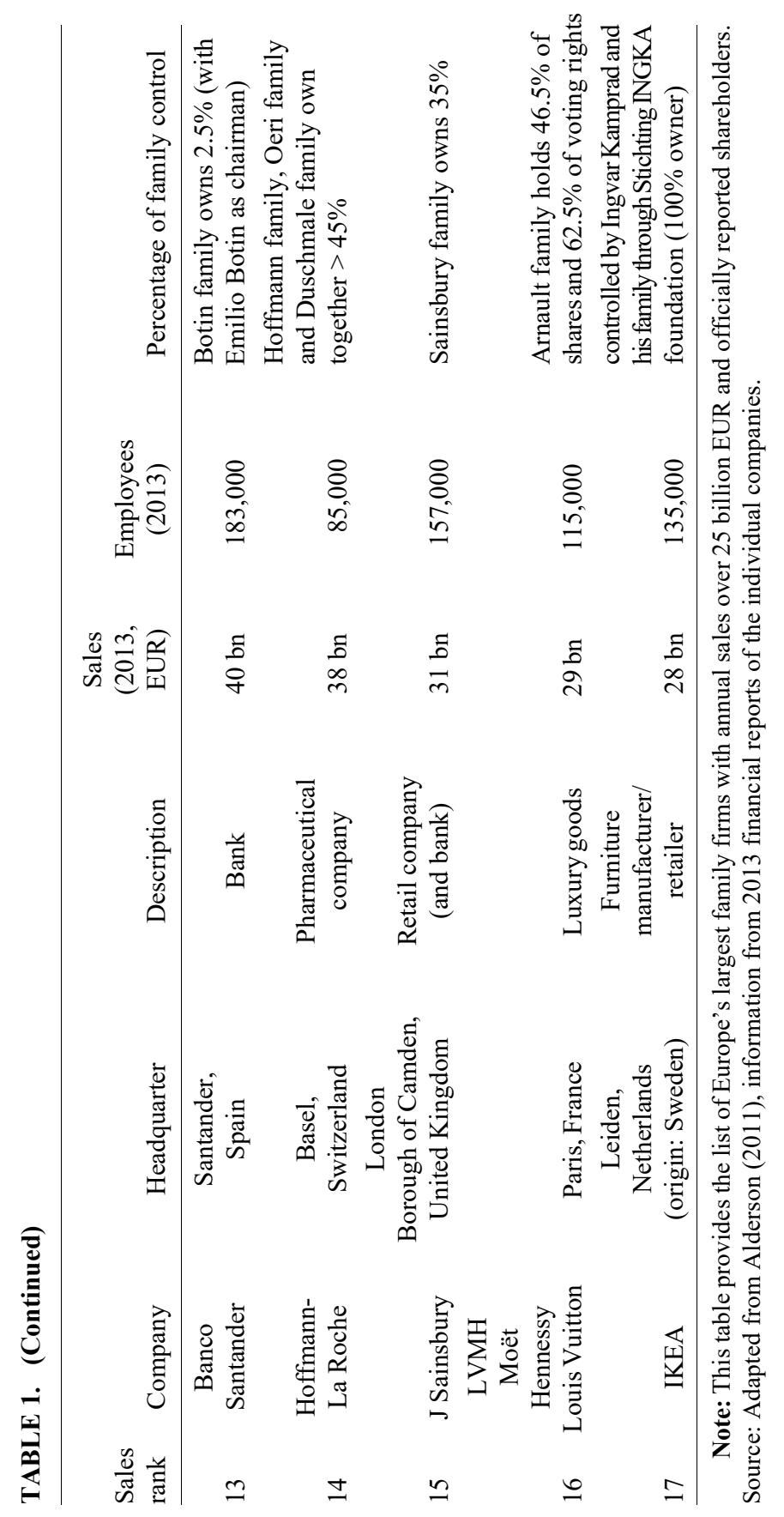


with substantial ownership, controlling families have the incentive and power to take actions that benefit themselves at the expense of the minority shareholders when their interests diverge from those of other shareholders (the so-called "tunneling or expropriation effect") (Morck and Yeung, 2003; Bertrand and Schoar, 2006). They might be able to expropriate wealth from the firm through related-party transactions, excessive compensation, or special dividends and pursue actions that maximize their personal utility respectively amenities leading to suboptimal policies and poor firm performance (Fama and Jensen, 1985; DeAngelo and DeAngelo, 2000; Dyer, 2006). Indeed, some studies point also to the existence of diverging interests between family blockholders and minority shareholders, which can lead to agency conflicts in some acquisition context. For example, Claessens et al. (2002) find for several East Asian economies that in the presence of control-enhancing mechanisms such as pyramid structures and dual-class share structures the firm value declines when the control rights of the largest shareholder exceed its cash-flow ownership. This pattern has also been confirmed by Holmen and Nivorozhkin (2007) for Sweden. Bauguess and Stegemoller (2008) argue that family firms are deeply entrenched and find that they destroy shareholder value when they undertake $M \& A$ transactions.

There are studies reporting that family firms experience less diversification than non-family firms (Anderson and Reeb, 2003b), and that with increasing concentration of ownership and personal wealth that is tied up in the family business, risky investments beyond the firm's range of expertise and knowledge will be less likely undertaken (Faccio, Marchica and Mura, 2011). This results in less industry-diversified acquisitions (Fahlenbrach, 2009). ${ }^{4}$ On the other hand, it can be observed that, especially in Continental Europe where the "insider financial system" dominates, family businesses are organized in form of pyramidal holding structures and family-controlled business groups (Masulis, Pham and Zein, 2011), which facilitate the internal financing of the family firm and the start-up of new diversifying businesses.

One can expect that family blockholders that attach a high value to control are interested in the sustainable, solid development of their firm in order to pass it over to next generations. For this purpose, they could

4. Fahlenbrach (2009) focuses more on pure CEO founder firms than on family firms in general. 
tend to mitigate the firm-specific risk through diversifying acquisitions (Miller, Le Breton-Miller and Lester, 2010). Miller, Le Breton-Miller and Lester (2010) provide empirical evidence for the propensity of family firms to make diversifying acquisitions by analyzing the Fortune 1000 companies (largest 1000 US firms by revenues) over the period from 1996 to 2000 . They argue that due to the family business owners' desire to keep a firm in the family for later generations and due to the fact that they cannot sell shares without losing control, the primary means by which families can avoid the concentration of their fortune within a single business is by diversifying the business itself. ${ }^{5}$

The desire of family blockholders to retain control in their business has also an impact on the method of payment of acquisitions and the price they pay for the target companies. Family owners tend to pay for acquisitions rather with cash than with stock in order to avoid dilution of their ownership and voting power and the creation of a new blockholder (Amihud, Lev and Travlos, 1990; Martin, 1996; Ghosh and Ruland, 1998; Faccio and Masulis, 2005; Caprio, Croci and Del Giudice, 2011). Pursuing long-term, sustainable investment strategies rather than myopic and detrimental ones, family firms are paying lower premiums in acquisition transactions showing again that there is no sign of expropriation of minority shareholders in family firms (Song, Ali and Pillay, 2008).

\section{B. Hypothesis development}

Most of the academic literature on family firms refers to the level of ownership when they aim at quantifying the importance of control in family firms. However, ownership alone could not be enough to fully capture control motives. Ellul (2008) and Croci, Doukas and Gonenc (2011) show that the desire of family blockholders to maintain control over their firms result in higher debt-equity ratios for these firms. The firm's capital structure and the underlying debt ratio might play an important role in affecting the type of acquisitions the firm is willing to conclude.

Family firms, in general, seem to be risk-averse and less diversified (Anderson and Reeb, 2003b; Faccio, Marchica and Mura, 2011;

5. May (1995) provides complementary results in the same direction. He finds that chief executive officers with more personal wealth vested in the firm's equity tend to diversify more in acquisitions than those who have a smaller participating stake. 
Fahlenbrach, 2009). However, Miller, Le Breton-Miller and Lester (2010) show that family firms tend to make more diversifying acquisitions because family blockholders do not want to sell shares and lose control. ${ }^{6}$ As a result, cross-industry diversifying deals represent an effective means to avoid concentration of family's wealth in a single line of business. This reasoning leads to our main testable hypothesis:

Family firms with blockholders valuing control high (i.e. family firms with high leverage) are more likely to pursue cross-industry diversifying deals.

Major shareholders who value control prefer financing investments by debt or cash rather than by issuing new stock as equity financing can dilute their voting power and increases the risk of losing control (see, e.g., Harris and Raviv, 1988; and Stulz, 1988). Amihud, Lev and Travlos (1990) examined the relation between corporate control and the means of financing of corporate acquisitions. They found that the use of cash financing is more likely, the larger the managerial ownership fraction of the acquiring firm and the more important the preserving control to bidder management. Similar results are provided by Faccio and Masulis (2005) and Caprio, Croci and Del Giudice (2011) who show that family firms prefer cash financing as payment method in merger and acquisition deals, especially when the continued voting control of their dominant shareholders is threatened. We, therefore, expect that the positive relation between "family owners that value control high (proxied by the firm's leverage)" and "cross-industry diversifying acquisitions" is more pronounced for cash-financed deals.

\section{Sample, variables, and descriptive statistics}

\section{A. Definition of family firms}

In the academic literature there are usually three main criteria which constitute the definition of family firms: (i) the proportion of ownership allocated to the family, (ii) the involvement of the family in board positions, and (iii) the corporate culture (family commitment towards the business).

6. May (1995) offers a similar explanation for acquisitions carried out by managers. 
Based on these criteria, several types of family firm definitions have been used in the past. Concerning listed companies, two main definitions are currently dominating the academic literature that focuses primarily on the ownership and control criteria: the founding family definition and the ultimate ownership definition.

The founding family definition takes into account whether the founding family of a company and its relatives hold certain percentages of voting rights of that particular company and/or whether the family members are represented in controlling bodies such as the board of directors (Anderson and Reeb, 2003a; Villalonga and Amit, 2006; Sraer and Thesmar, 2007; Andres, 2008). Depending on the corporate governance structures of the various countries, different ownership threshold values apply in order to exercise a significant controlling influence on the company (usually $5 \%$ in the US whereas in Continental Europe higher values are applicable, such as $20 \%$ in France and $25 \%$ in Germany, i.e. $25 \%$ of ownership are required in Germany in order to be able to block certain decisions in shareholder meetings).

The ultimate ownership definition does not consider the fact whether a family or private person has founded the company but whether they hold a controlling ownership stake (La Porta, Lopez-de-Silanes and Shleifer, 1999; Faccio and Lang, 2002). In that case the entire ownership structure including any complex pyramidal shareholder and cross equity investments are screened in order to examine whether there exists a controlling shareholder. If this shareholder represents a family or private person, then the respective company meets the definition requirement of a family firm regardless of whether the shareholder was involved in the firm foundation or not.

The definitions above are classified as dichotomous since they categorize the companies as either family or non-family firms. Astrachan, Klein and Smyrnios (2002) propose a continuous measure for family influence on a company. They compile an index of family influence on power, experience, and culture (F-PEC index). Power refers to the ownership and management positions of the family. Experience accounts for the age of the company and the number of family generations, and culture focuses on the degree of family commitment towards their business. The culture criterion is quite difficult to be measured objectively. It might be captured by qualitative research approaches such as questionnaires.

A further approach to define family firms and to measure the influence of family on the company in a continuous manner has been 
presented by Klein $(2000,2004)$ under the concept of substantial family influence where she refers to the following components: the percentage family share of the company's equity capital, the percentage family share in top management positions of the company, and the percentage family share in the board of directors. The sum of all components needs to be equal to $100 \%$ in order to suffice the family definition, i.e. a lower share in one component can be compensated by a higher share in another component. However, the ownership share of the family shall never be $0 \%$. This definition is classified as very stringent. Originally, it has been constructed for private, non-listed family firms where the family's ownership is rather concentrated. In case of listed family firms, the family's ownership is usually less concentrated due to the free-float of a certain portion of shares which are publicly held.

The substantial family influence method is only suitable for private firms and the culture subscale of F-PEC index is hardly quantifiable. Therefore, only the founding family and the ultimate ownership definition remain eligible for application to public firms (over $80 \%$ of the European company sample represent listed firms). The reason why we adopt the ultimate ownership definition as suggested by La Porta, Lopez-de-Silanes and Shleifer (1999) and Faccio and Lang (2002) is the existence of many companies in which the influence and involvement of family blockholders are as significant as in the role of founding families although they have not directly founded the company. Excluding family firms where the family blockholders do not belong to the group of founding members might therefore produce a misleading picture of significant family ownership influence.

Following Franks et al. (2012) a threshold level of $25 \%$ will be applied in this study for the ultimate ownership whereas ultimate ownership represents the control of voting rights. ${ }^{\text {? }}$

\section{B. Description of sample and data sources}

Ownership data for the European firms has been retrieved from Bureau van Dijk's database Amadeus that tracks also the shareholder's history of the companies. All reported public (listed and delisted) companies in Europe ( 40 different countries) have been considered if a valid company

7. La Porta, Lopez-de-Silanes and Shleifer (1999) as well as Faccio and Lang (2002) use a threshold level of $20 \%$. Faccio and Masulis (2005) report that the level of voting power in the range of $20-60 \%$ is the range where the blockholders are most vulnerable to a loss of control. Hence, a threshold level of $25 \%$ is reasonable based on existing literature. 
identifier such as SEDOL number was available. A company has been set as family firm if "one or more named individuals or families" are reported as ultimate ownership type whereas an ownership threshold level of $25 \%$ (percentage of voting rights) has been applied. The shareholder's histories of the respective companies have also been checked to make sure that the assigned ownership type is valid over the entire history of sample data. Table 2 gives an overview of the underlying firm sample distinguishing between family and non-family firms broken down on regional level including information on mean total assets and age of the companies in the different regions. In total, 10,031 firms have been identified with a clear assignable ownership type of which $31 \%$ represent family firms. ${ }^{8}$ Across the entire dataset the results show that family firms are on average in Europe (statistically significant) younger than non-family firms and have also a smaller balance sheet. Family firms are most prevalent in France, Germany, and Eastern Europe.

To analyze the propensity for cross-industry diversification of family firms this study requires a sample of M\&A transactions in which family and non-family firms are involved as bidders. We start with all mergers and acquisitions announced over the period 1990-2013 which have been reported in Thomson Reuters SDC M\&A Database. The sample includes all transactions of a certain size (i.e., deal size greater than 1 million USD or larger than $1 \%$ of the acquirer's market capitalization) where the bidding firm is located in Europe (with no restriction on the target firm nationality) and where information is available on the ownership type of the bidder. This leads to the identification of 20,693 announced deals by our sample firms. The acquisition sample also includes minority deals. We kept minority deals in the sample because the intention behind diversification is not necessarily to have a controlling stake in the target firm but to diversify over several smaller stakes in different companies.

Table 3 presents an overview of the sample. On average in $17 \%$ of these deals family firms were involved as acquirers. The table also shows that in the years 2008, 2009, 2011 and 2013 the family firm portion in overall M\&A activity was higher than usual.

To construct the relevant variables (dependent, key independent and

8. The percentage of family firms is not as high as referred to in the literature above since the sample includes only firms where a valid company identifier (SEDOL) is available and excludes a large number of private firms. 


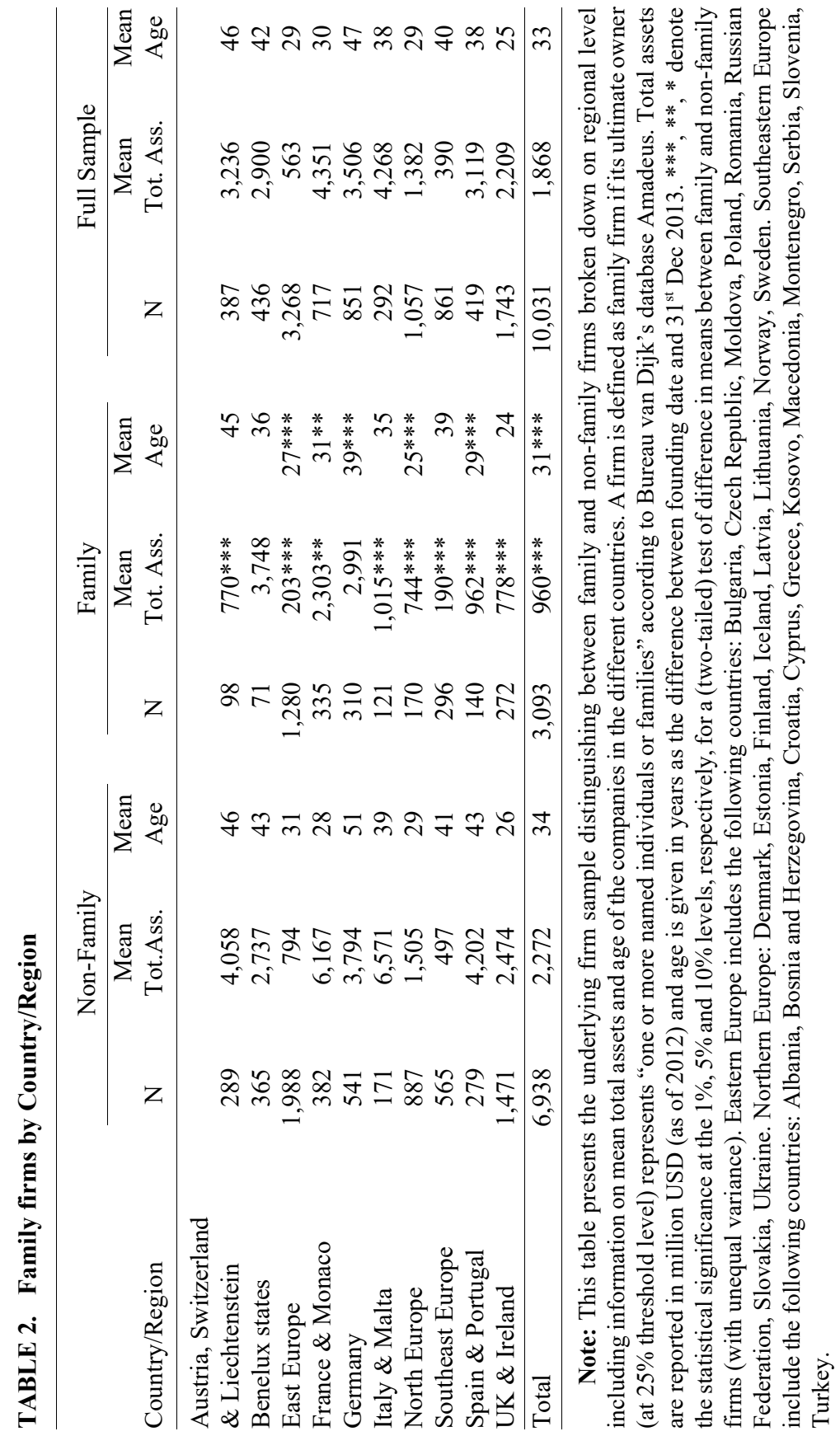




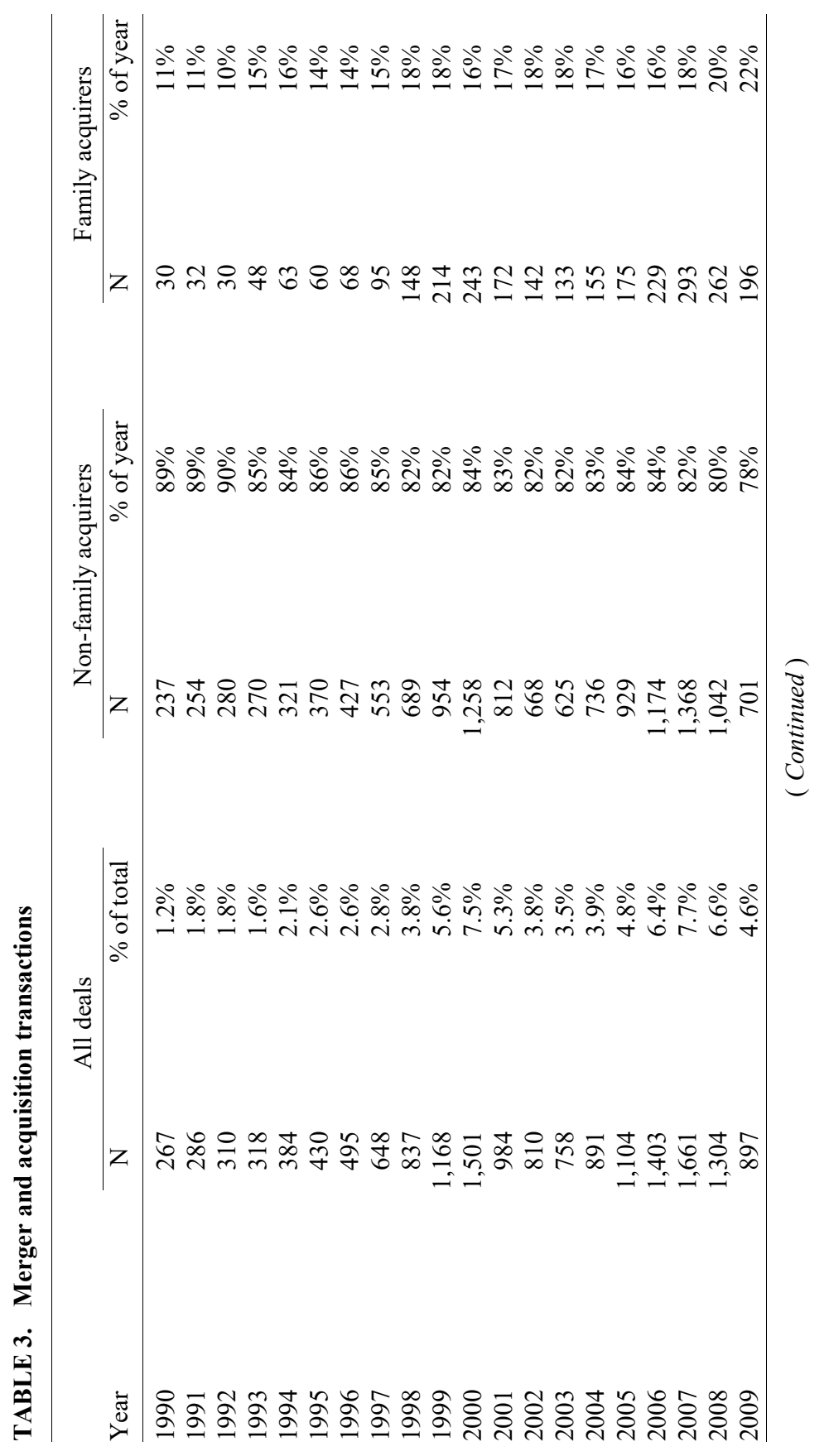




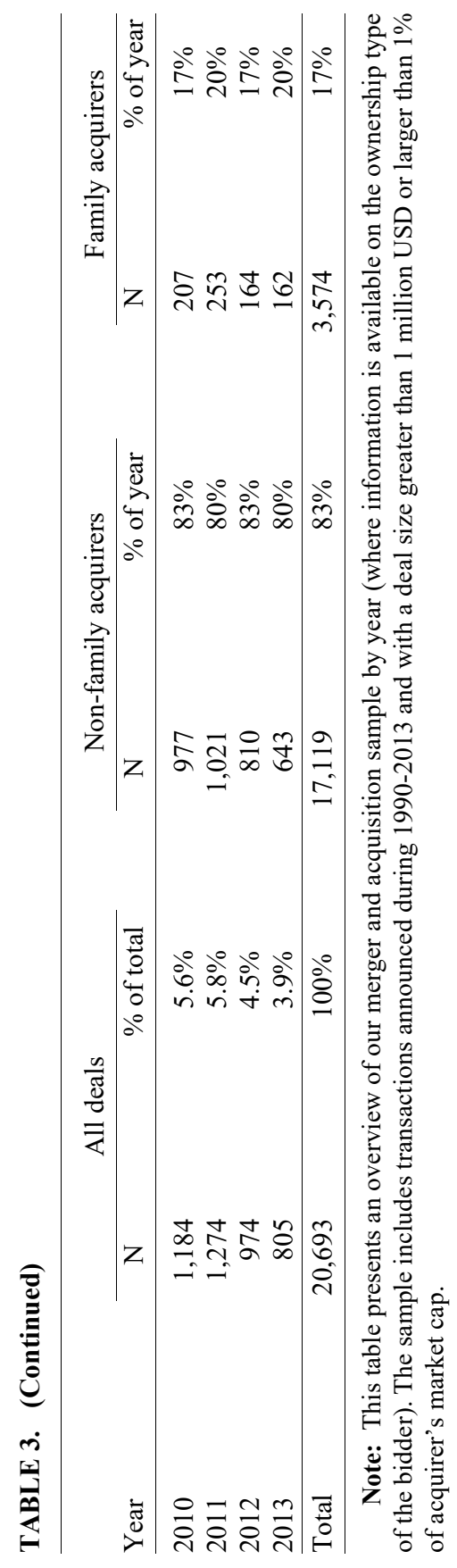


control variables) which will be described in the next section in more detail, we need apart from deal-relevant data reported in Thomson Reuters SDC also financial market/security prices and accounting data for the different companies involved in the merger and acquisition deals. The sources for these latter data are Thomson Reuters Datastream (for security prices) and Thomson Reuters Worldscope (for accounting data). For the empirical analysis yearly accounting data has accordingly been chosen as per year end prior to the date of deal announcement as only available information at announcement date can be used to test the influence on the transactions. In addition, all variables have been winsorized at $1^{\text {st }}$ and $99^{\text {th }}$ percentile to attenuate the effect of outliers on our analyses.

\section{Definition of variables}

A summary of the description of all variables used in this study can be found in the appendix.

\section{Independent variables of interest}

The goal of this study is to analyze the impact of the value of control in family firms on merger and acquisition transactions whereas the value of control is captured by the interaction between family firms and their leverage. Hence, the main key independent variable is represented by the interaction term respectively the product of the family dummy variable "FD" (taking the value of 1 if the ultimate owner represents "one or more named individuals or families" according to the database Amadeus, and 0 otherwise) and the firm's leverage ratio "Lev" (defined as the book value of the firm's debt divided by its total assets, as per year end prior to the M\&A announcement). To examine the influence of the debt maturity, we additionally split the firm's leverage ratio into two components, namely the short-term debt "STdebt" and long-term debt "LTdebt" (defined as the book value of the firm's short-term respectively long-term debt divided by its total assets).

The interaction term between the family dummy and leverage ratio represents the main key independent variable of interest if the full sample is considered including family and non-family firms. Alternatively, the study also analyzes the subsample of family firms 
alone. In that case the leverage itself represents the main independent variable of interest. ${ }^{9}$

\section{Dependent variables}

To explore the impact of value of control in family firms in the context of merger and acquisition decisions, we consider the following two dependent variables: (i) the propensity to undertake diversifying transactions and (ii) the bidder's stock performance associated with the corresponding transaction.

We use the dummy variable "CrossIndustry" in order to identify cross-industry deals. The variable takes the value of 1 if the bidder's and target firm's industry differ from each other based on the 2-digit Standard Industrial Classification (SIC) code, else it takes the value of $0 .{ }^{10}$ To test our conjecture about the relation between control in family firms and cash-financed cross-industry deals, we modify the dummy variable to "CrossIndustryCash" which takes the value of 1 if the identified cross-industry deals are mainly financed with cash (i.e., at least $50 \%$ of the deal financing is cash), and 0 otherwise. To measure the bidder's performance, we rely on short term event study methodology and compute announcement cumulative abnormal returns $\left(\mathrm{CAR}_{\mathrm{Acq}}\right)$. We use an event window of three days around the deal announcement date, as it is common in the M\&A literature. Our results are qualitatively the same if we use a five-day event window (unreported). Following Brown and Warner $(1980,1985)$ who show that there is no significant difference between the market model and the standard beta one model (market adjusted returns), we apply the latter one where the abnormal returns represent the excess returns of the firm's stock against its benchmark (local market index). ${ }^{11}$ Stock and index prices are from Datastream.

\section{Control variables}

To model the propensity to undertake cross-industry deals, we control

9. This study focuses on leverage to measure how much blockholders value control. Ellul (2008) shows namely that the firm's leverage ratio is able to substitute the wedge (i.e. the excess voting rights over cash flow rights).

10. Based on Herger and McCorriston (2014) the 2-digit SIC level excludes any bias of vertically integrated deals and is reasonable to separate diversified from non-diversified deals across industries (Miller, Le Breton-Miller and Lester, 2010).

11. Aktas, de Bodt and Roll (2004) show that there is no significant difference in the results between using local currencies or converting all prices into one common currency. 


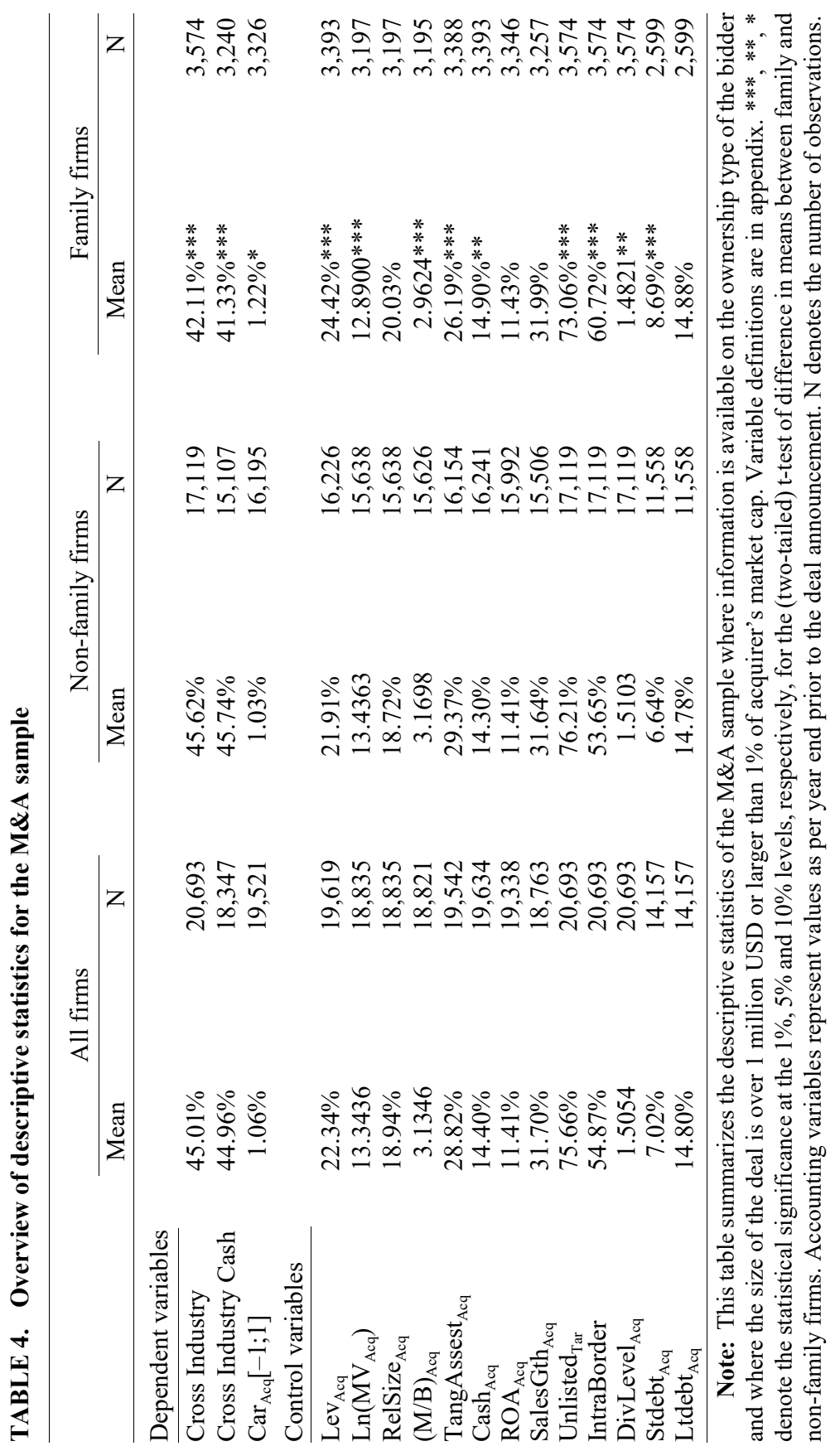


following Miller, Le Breton-Miller and Lester (2010), among others, for the size of the firm (i.e., natural logarithm of the firm's market value of equity), for its growth opportunities (using both the firm's market-to-book ratio and sales growth), cash holding, degree of diversification, and operating performance (return on assets). Following the extant literature (see, e.g., Betton, Eckbo and Thorburn, 2008; Alexandridis, Petmezas and Travlos, 2010), in the abnormal return regressions we control, among others, for the bidder's market-to-book ratio, deal size, a dummy variable identifying stock deals, deal size, relative size of the transaction with respect to the bidder size and the listing status of the target.

\section{Univariate analysis}

Table 4 summarizes the descriptive statistics of the mergers and acquisitions deal sample. Family firms are slightly less inclined to announce cross-industry deals than their non-family counterparts, which is in line with some previous studies (Anderson and Reeb, 2003b; Faccio, Marchica and Mura, 2011; Fahlenbrach, 2009) reporting that family firms are in general more risk-averse and hence less diversified since cross-industry transactions might be regarded as risky investments due to the lack of synergies and relatedness between bidder's and target firm's activities.

In addition, the univariate results indicate that family firms create a slightly higher value through their acquisitions compared to non-family firms which has also been documented by Ben-Amar and Andre (2006), Basu, Dimitrova and Paeglis (2009), Sraer and Thesmar (2007) as well as Bouzgarrou and Navatte (2013) although the difference in announcement returns between family and non-family bidders are only marginally significant in our analysis. In addition, table 4 shows that (bidding) family firms have a higher leverage ratio than non-family firms which is consistent with the findings in Ellul (2008). Family firms tend to be also relatively smaller in comparison to non-family firms. They hold larger cash portions and pursue more domestic transactions (deals within one country and not cross-country) than non-family firms which is again a sign for risk-averse behavior.

\section{Empirical results}

\section{A. Cross-industry diversification}

To explore the impact of the family blockholder's aspiration for control 
on the propensity of cross-industry diversification in M\&A deals, we conduct probit regressions in table 5 and present the results in three different panels. In all regressions the specification accounts for country, industry, and year fixed effects in order to control for time-invariant country and industry effects, as well as to account for time trend. The full sample includes family and non-family firms whereas the subsamples account for family and non-family firms separately. The samples include all merger and acquisition transactions (all deal types including minority deals). Accounting variables refer to the year-end prior to the date of deal announcement. Test statistics are calculated based on Huber/White robust standard errors. All ratios are winsorized at the $1^{\text {st }}$ and $99^{\text {th }}$ percentile to eliminate any outliers.

In Panel A of table 5 the dependent variable represents a dummy variable which identifies cross-industry deals (i.e. the variable takes the value of one if the acquirer and the target belong to different industries at 2-digit SIC code level, and zero otherwise). In the first four columns, we report the estimates of two different model specifications for the full sample. The coefficient estimate of the family dummy variable $\left(\mathrm{FD}_{\mathrm{Acq}}\right)$ in the first model is negative and statistically significant. This result shows that family firms in our sample tend to do less diversifying merger and acquisition deals in comparison to non-family firms. The corresponding marginal effect reported in the second column indicates that the likelihood to undertake cross-industry deals is $2 \%$ lower for family firms in comparison to non-family firms. This finding is consistent to a large extent with previous literature (Anderson and Reeb, 2003b; Faccio, Marchica and Mura, 2011; Fahlenbrach, 2009) as family firms are regarded as risk-averse companies which avoid any risky investments. Cross-industry acquisitions can be risky due to the lack of knowledge and expertise of the bidding firm in that particular industry as well as lack of operating synergies.

In the second model specification, to account for the attitude toward control of the family shareholder, we add the interaction between the leverage ratio of the bidder and the family dummy $\left(\operatorname{Lev}_{\mathrm{Acq}} \times \mathrm{FD}_{\mathrm{Acq}}\right)$. The interaction term is positive and statistically significant; indicating that the higher the leverage of the family firm, the more likely is cross-industry diversification. This result is consistent with our hypothesis: family firms with blockholders valuing control high (i.e, family firms with high leverage) are inclined to make more cross-industry diversifying acquisitions. Our finding is also supported by the (strongly statistically significant) positive leverage coefficient in 
the family firm sub-sample. The motivation behind such cross-industry transactions are due to the fact that family blockholders valuing control high are reluctant to sell shares and lose control and that cross-industry diversifying deals are an effective mean to avoid concentration of family's wealth in one industry. Hence, such transactions can be explained by the control motives of the family blockholders and their aspiration to diversify their wealth.

The results in the second model specification for the full sample show in addition that that the likelihood to undertake cross-industry deals is $4.6 \%$ lower for non-levered family firms in comparison to levered family firms. With increasing leverage, the value of control and the desire to diversify becomes more important to family blockholders. If the leverage in family firms is higher than $42 \%$, the overall proneness of family firms to cross-industry diversification is positive, indicating that only in highly levered family firms the blockholders are expected to value control high. ${ }^{12}$

Concerning the control variables, lower tangible assets, cash holdings, and profitability of the bidding firm are associated with higher cross-industry acquisition activity. It seems that firms which are not doing that well in their current core industry seek additional opportunities outside of their core business to compensate for. One can also see that diversified bidding firms are more likely to do cross-industry deals. While highly diversified firms may not have incentives to further diversify, they may also want to carry out acquisitions to strengthen their competitive positions in their non-primary industries which could explain the positive effect of the diversification proxy on the probability to complete a diversifying deal. ${ }^{13}$

Previous studies have shown that the desire of family blockholders to preserve control affects the method of payment in M\&A transactions; bidding family firms tend to use rather cash than stocks to finance M\&A deals, especially when the continued voting control of their dominant

12. The analysis of family firms' leverage in our sample reveals that the third quartile and maximum leverage are $36.26 \%$ and $71.92 \%$, respectively, which shows that the threshold result seems to be reasonable.

13. The firm's degree of diversification is defined as the number of industries (at 2-digit SIC codel level) in which the firm is active prior to deal announcement. Alternatively, we have also applied a different defini-tion based on the Herfindahl-Hirschman-Index with respect to the firm's sales in the individual industries it operates. The results are qualitatively similar and available upon request. 


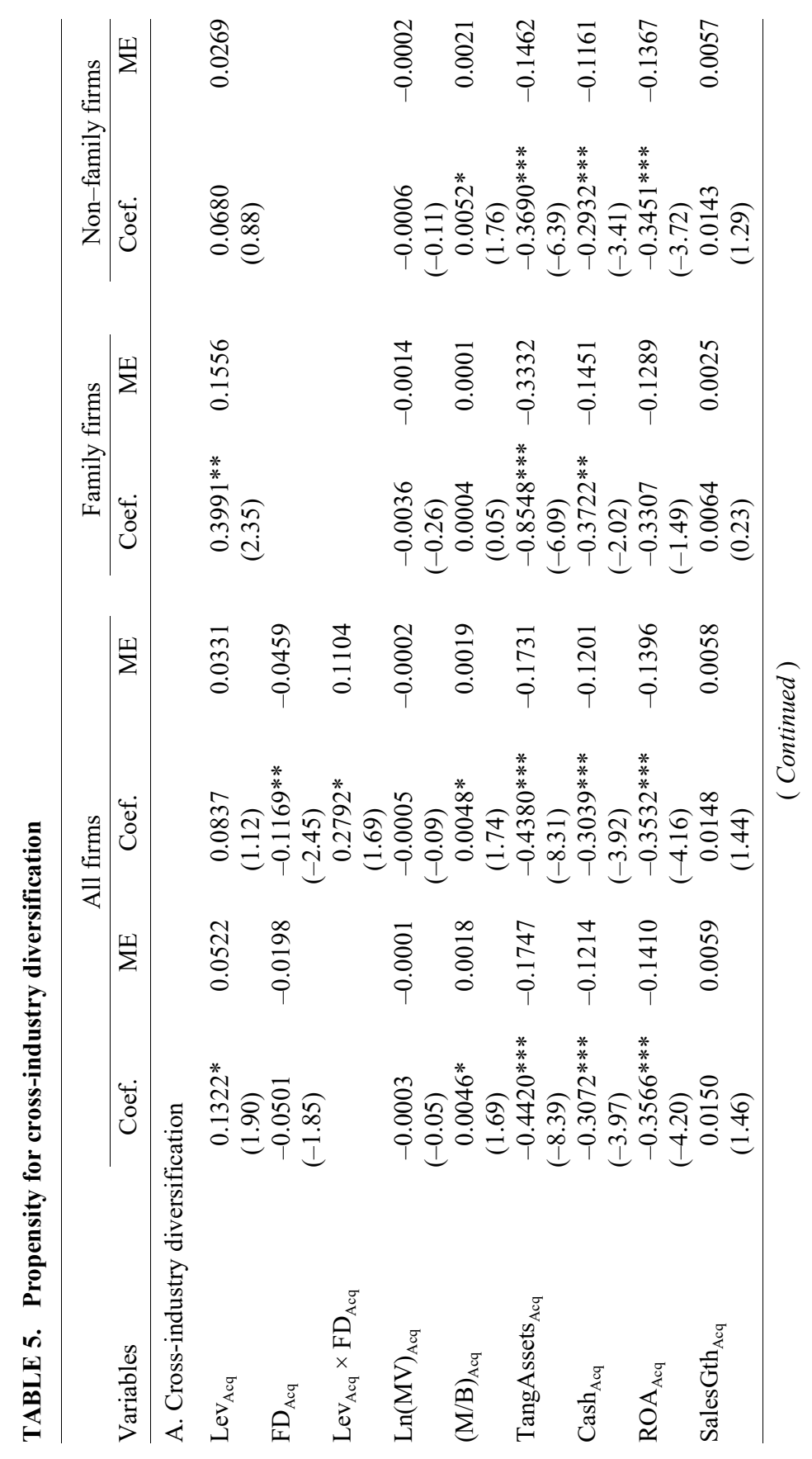


Value of Control in Family Firms: Evidence from Mergers and Acquisitions

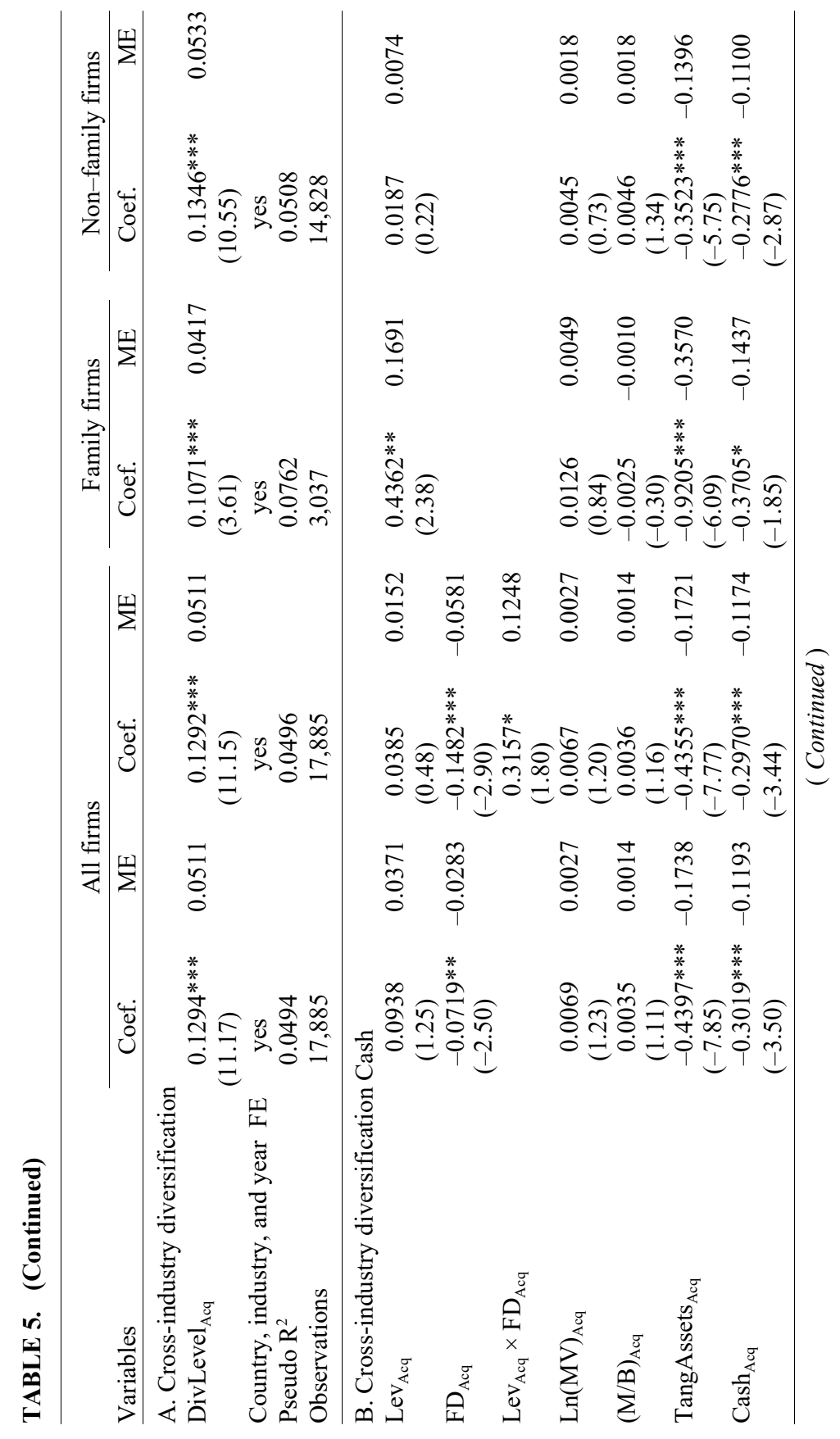




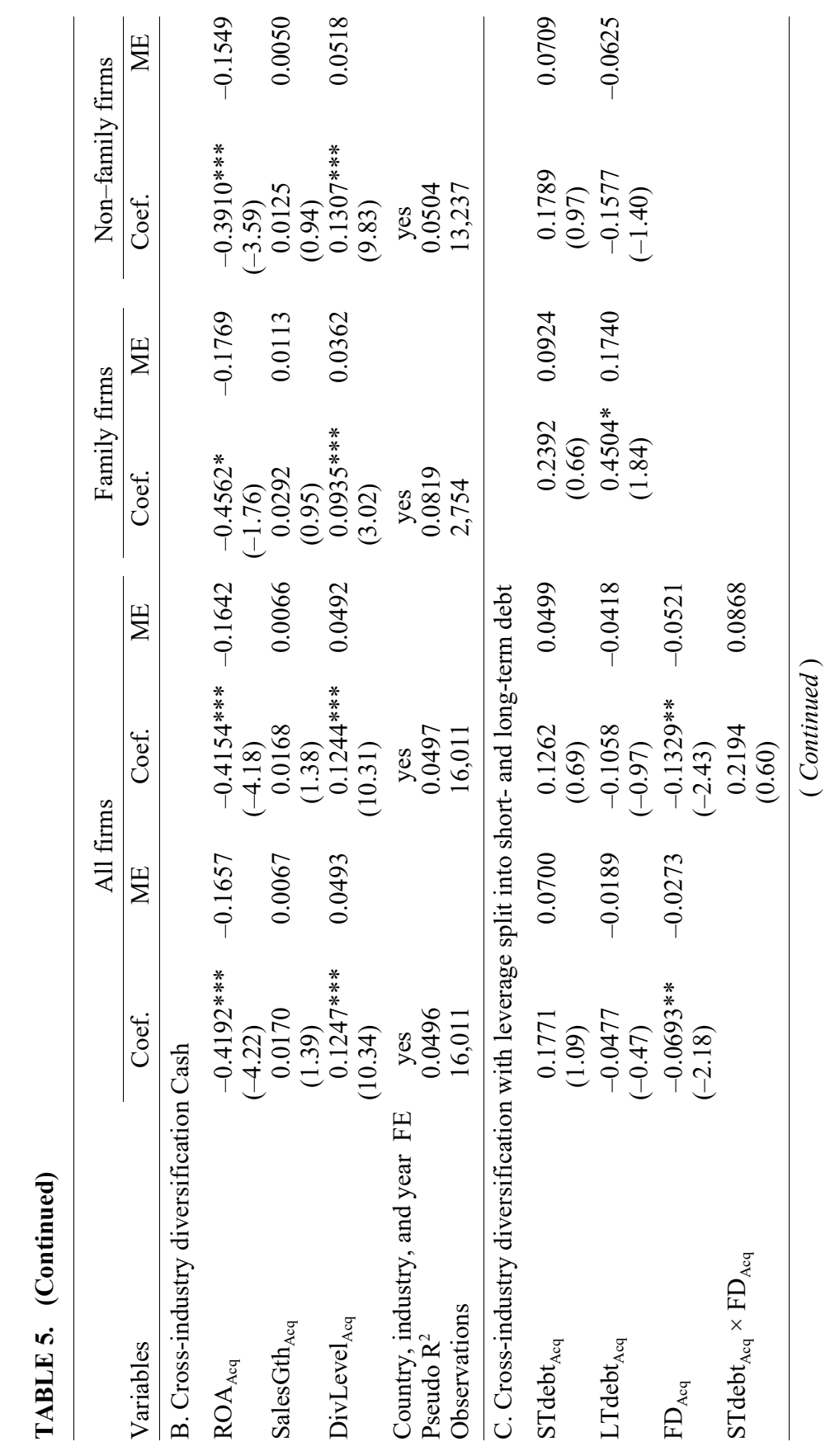




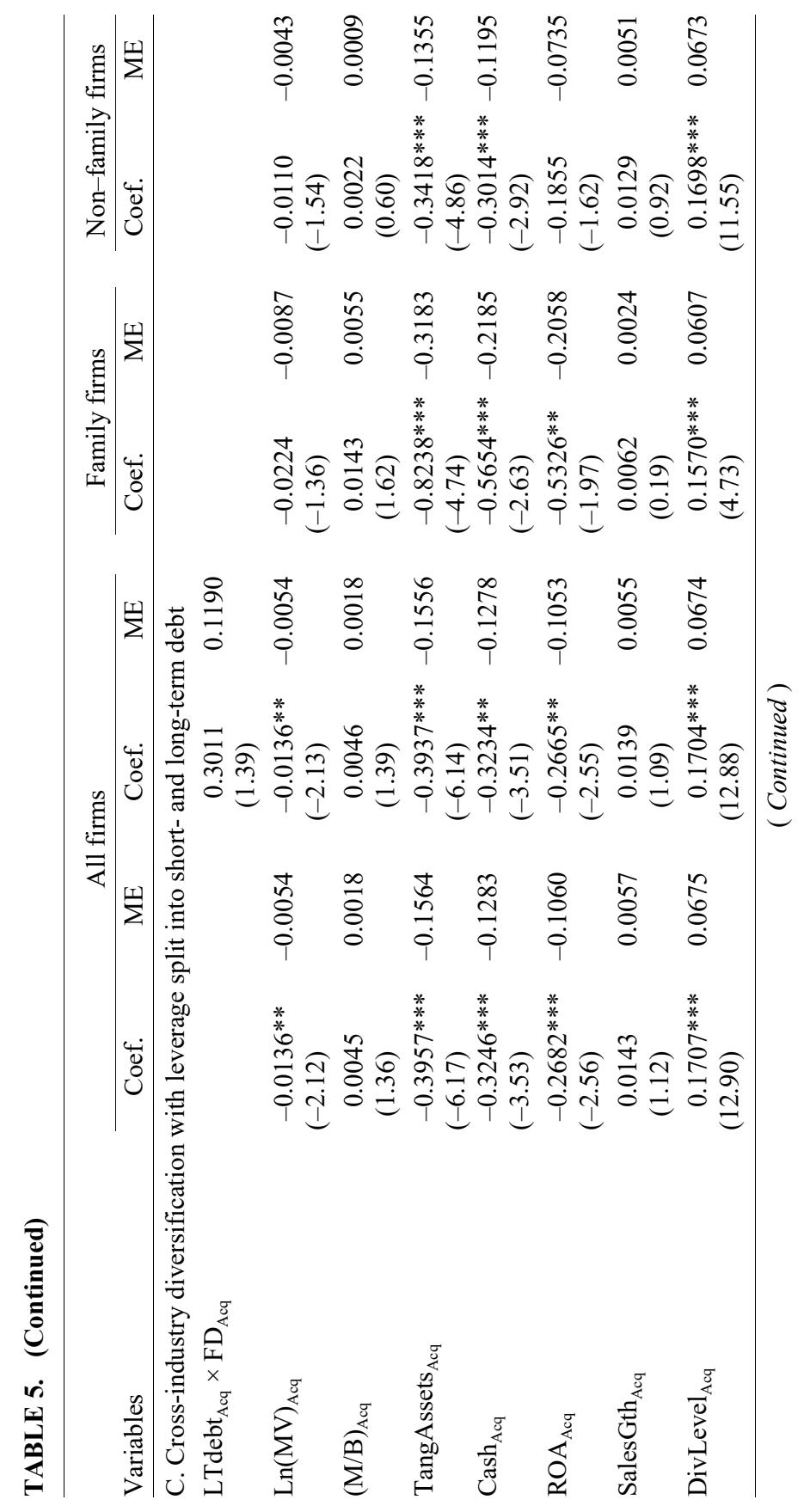




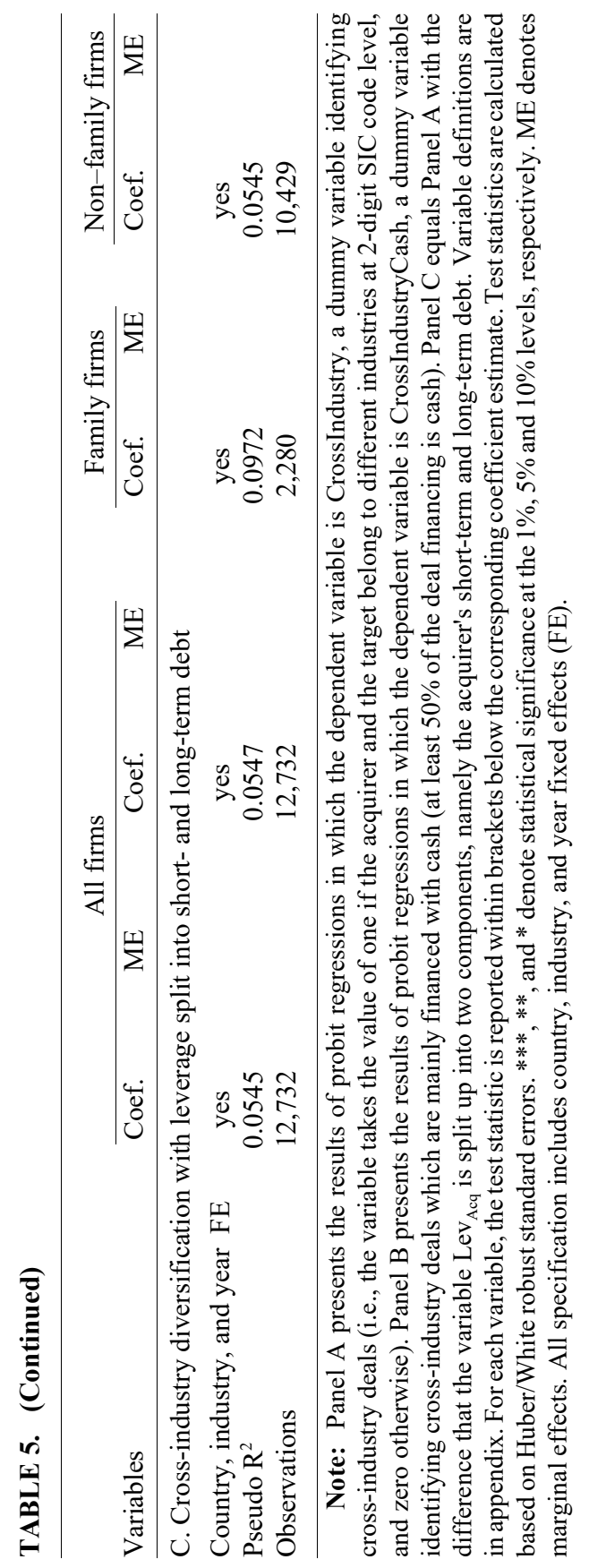


shareholders is threatened (Faccio and Masulis, 2005; Caprio, Croci and Del Giudice, 2011). We, therefore, assume that the relation between "family owners that value control high (proxied by the firm's leverage)" and "cross-industry diversifying acquisitions" is stronger for cash-financed acquisitions. To test this conjecture, we replicate the analysis in Panel A of table 5 by using a sample of cash deals. The dependent variable is modified accordingly to identify only cross-industry deals for which the payment method is mainly cash (i.e., the cash portion is higher than 50\%). The result of this analysis is reported in Panel B of table 5. The coefficient estimates of our variables of interest, $\mathrm{Lev}_{\mathrm{Acq}} \times \mathrm{FD}_{\mathrm{Acq}}$ for the full sample specification and $\mathrm{Lev}_{\mathrm{Acq}}$ for the family firm sub-sample, are positive and statistically significant. Comparing the marginal effects of both variables with the corresponding marginal effects in Panel A, we can observe an increase by $13.6 \%$ (from 0.110 to 0.125 ) and $8.3 \%$ (from 0.156 to 0.169 ), respectively. Consistent with our intuition, the positive effect of leverage on diversifying acquisitions for family firms appears to be more pronounced in the subsample of cash transactions.

Croci, Doukas and Gonenc (2011) studied the relation between family-controlled firms and their debt maturity structure. They have shown that family firms are more likely to issue long-term than short-term debt. Credit markets perceive family blockholders as risk averse since most of the shareholders' wealth is invested in their own firms which discourages managerial risk taking. The lower risk incentives in family firms lead to lower agency costs of debt which, in turn, make long-term debt more affordable. To analyze the influence of the family blockholder's desire to retain control (proxied by the firm's leverage) on the propensity of cross-industry diversification in light of different debt maturities, we replicate Panel A of table 5 and modify the respective model specifications by splitting the acquirer's leverage ratio $\mathrm{Lev}_{\text {Acq }}$ into two components, namely the short-term debt STdebt (representing the portion of debt payable within one year scaled by the firm's total assets) and long-term debt LTdebt $_{\mathrm{Acq}}$ (corresponding to all interest-bearing financial obligations, excluding payments due within one year, divided by the firm's total assets). The estimation results are reported in Panel $\mathrm{C}$ of table 5. Consistent with the findings of Croci, Doukas and Gonenc (2011), we observe that the documented leverage effect on cross-industry diversifying acquisitions for family firms appears to be driven by long-term debt (reflected by the statistically significant positive coefficient for LTdebt $_{\mathrm{Acq}}$ in the family firm 
sub-sample). Family firms are known to be conservative and risk averse (see, for example, Zhou, Li and Svejnar, 2011, and Caprio, Croci and Del Giudice, 2011). These traits explain why family firms prefer long-term to short-term debt. Short-term debt leaves the firms exposed to the risk of unexpected interest rate increases and liquidity bottlenecks whereas long-term debt mitigates this risk exposure. Family firms with high long-term debt are more likely to be the ones with strongest control and diversification aspiration as they gain most from cross-industry diversifying acquisitions, due to the fact that these investments help stabilize the firm's cash flows reducing the likelihood of financial distress and lowering further the debt agency costs.

\section{B. Additional results and robustness checks}

There might be some concerns that the leverage ratio is changing over time and increasing shortly before an acquisition is planned. To mitigate this potential bias, we use a new variable of interest AvgLev $_{\text {Acq }}$ which represents the average of the acquirer's firm leverage over the last five years prior to the deal's announcement. The result is presented in Panel A of table 6 and confirms the robustness of our initial findings.

So far our regressions use a dummy variable identifying cross-industry bidders and therefore do not account for the intensity of the firm's M\&A activity in the corresponding year. To control for acquisition intensity, the dependent variable in Panel B of table 6 is defined as the number of diversified deals divided by the total number of deals of a firm in a given year provided that the firm is undertaking a deal in that year. As the dependent variable takes values between 0 and 1 , we rely on a tobit specification. Results are once again consistent with our hypothesis.

Having assessed the robustness of our main finding, we next analyze whether cross-industry deals are implemented by family firms at the expense of minority shareholders. To do so, we analyze wealth effects associated with acquisition decisions by regressing bidder's announcement cumulative abnormal returns (CARs) on firm leverage, a dummy variable identifying family firms, a dummy variable identifying cross-industry deals, their interactions, and additional control variables. Test statistics are calculated based on firm-clustered robust standard errors. In all regressions, the specification accounts for country, industry, and year dummies.

Table 7 reports the results of three different specifications. The first 


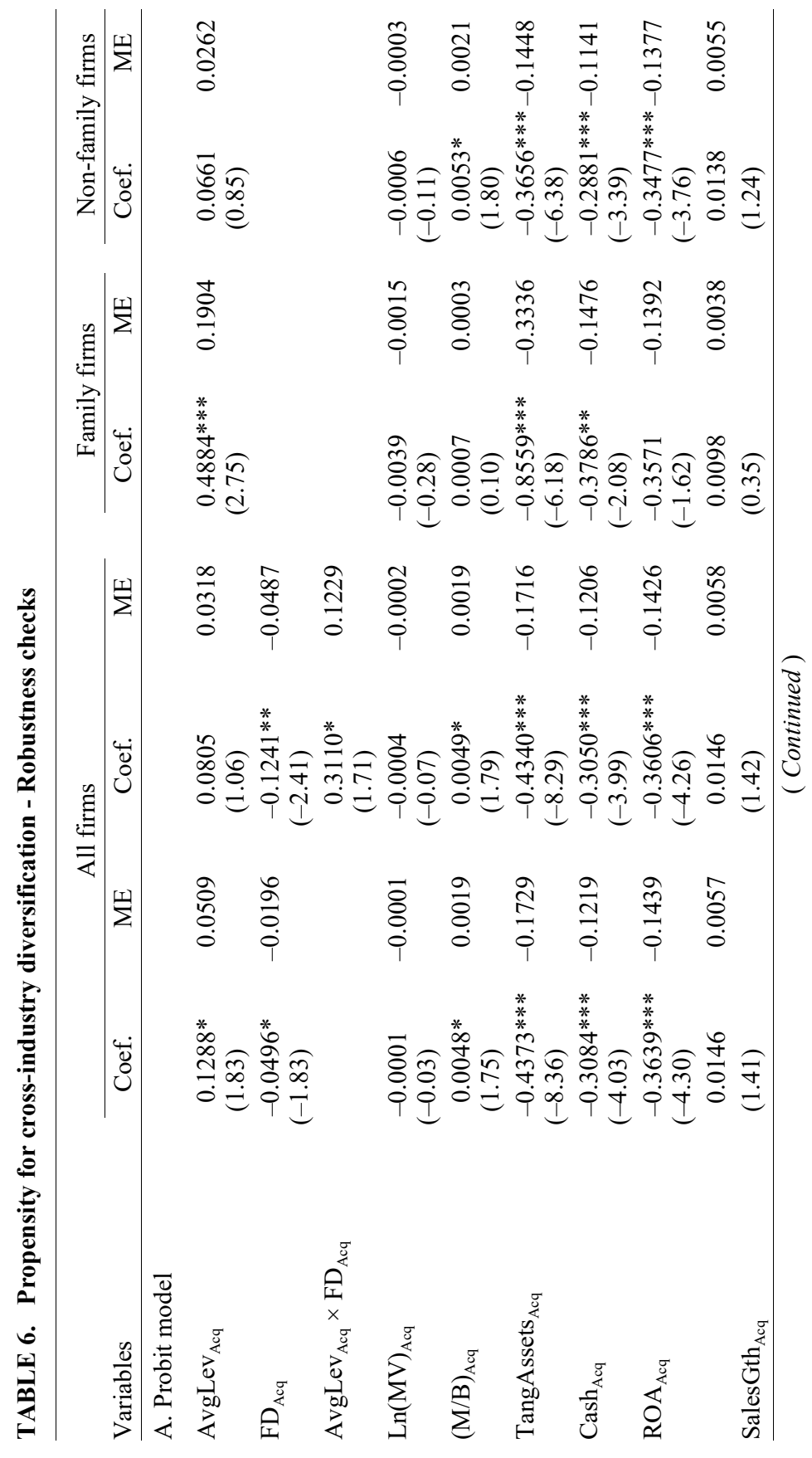




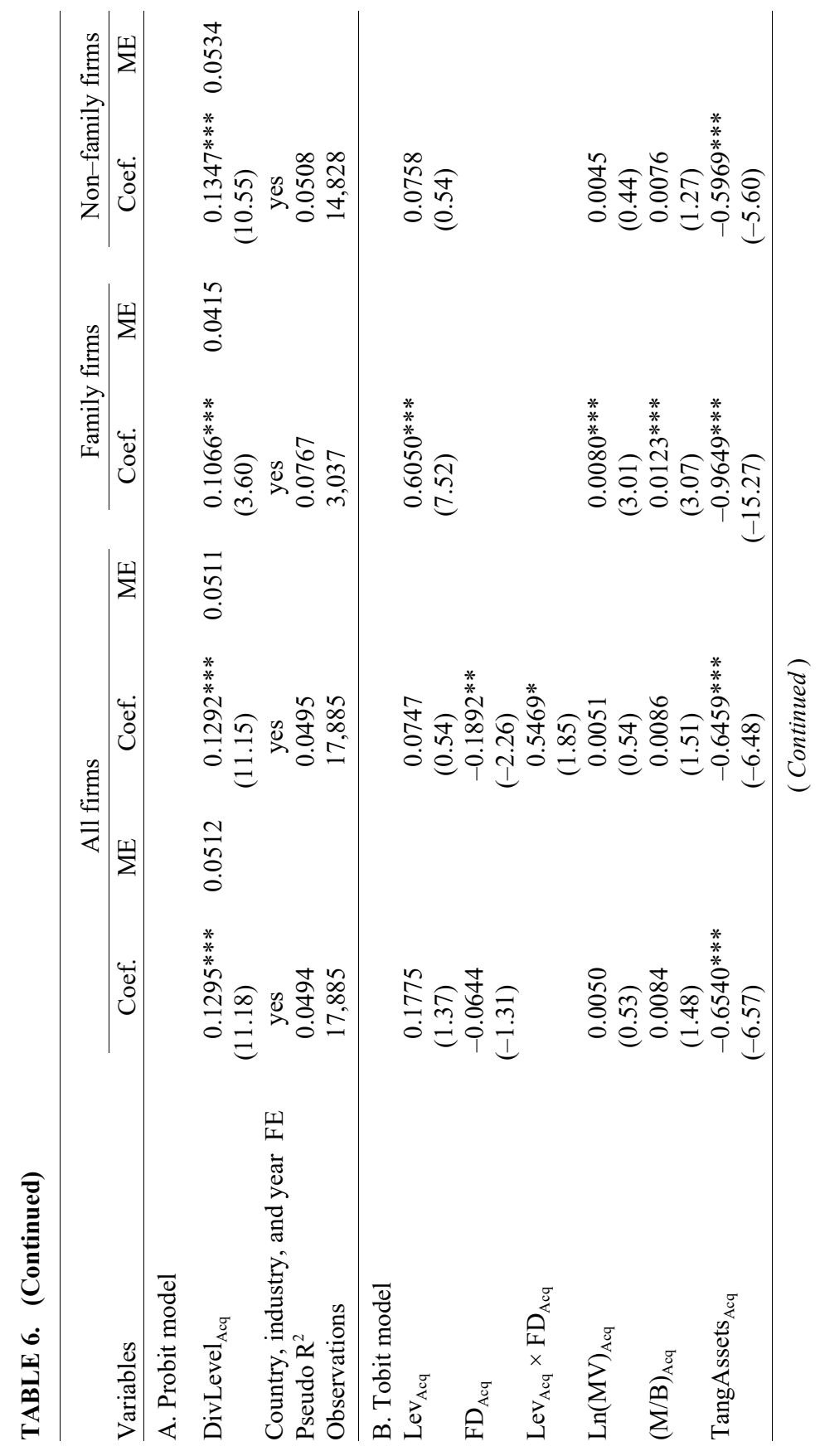


Value of Control in Family Firms: Evidence from Mergers and Acquisitions

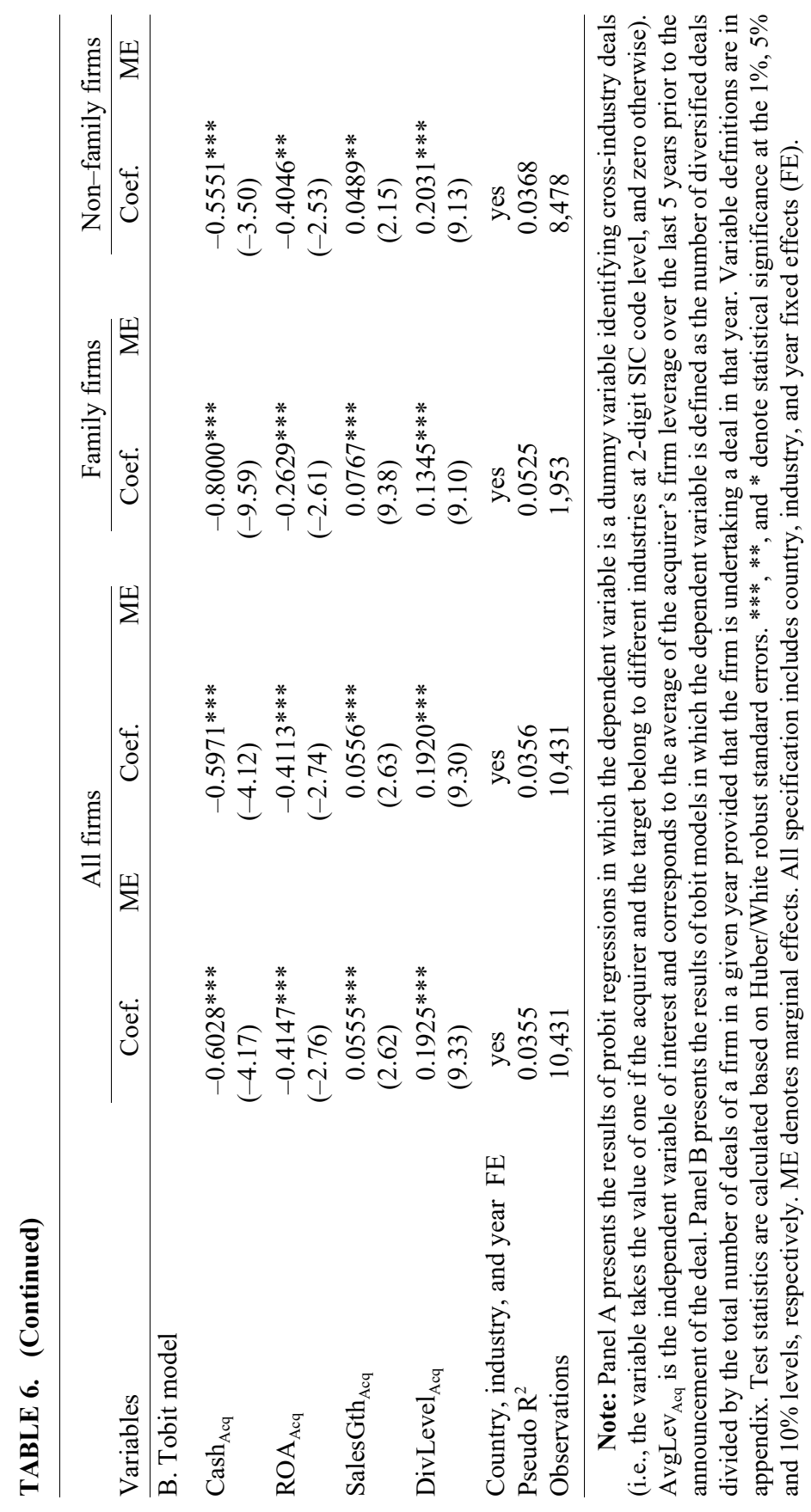


TABLE 7. Acquirer CAR regressions

\begin{tabular}{|c|c|c|c|}
\hline Variables & (1) & (2) & (3) \\
\hline $\operatorname{Lev}_{\text {Acq }}$ & $\begin{array}{l}0.0019 \\
(0.35)\end{array}$ & $\begin{array}{l}0.0048 \\
(0.74)\end{array}$ & $\begin{array}{l}0.0049 \\
(0.76)\end{array}$ \\
\hline $\mathrm{FD}_{\mathrm{Acq}}$ & $\begin{array}{l}0.0017 \\
(1.06)\end{array}$ & $\begin{array}{l}0.0050^{*} \\
(1.76)\end{array}$ & $\begin{array}{l}0.0052^{*} \\
(1.90)\end{array}$ \\
\hline $\mathrm{Lev}_{\mathrm{Acq}} \times \mathrm{FD}_{\mathrm{Acq}}$ & & $\begin{array}{l}-0.0138 \\
(-1.24)\end{array}$ & $\begin{array}{l}-0.0108 \\
(-0.87)\end{array}$ \\
\hline CrossIndustry & $\begin{array}{l}-0.0014 \\
(-1.21)\end{array}$ & $\begin{array}{l}-0.0014 \\
(-1.19)\end{array}$ & $\begin{array}{l}-0.0010 \\
(-0.79)\end{array}$ \\
\hline CrossIndustry $\times \operatorname{Lev}_{\mathrm{Acq}} \times \mathrm{FD}_{\mathrm{Acq}}$ & & & $\begin{array}{l}-0.0088 \\
(-0.82)\end{array}$ \\
\hline$(\mathrm{M} / \mathrm{B})_{\mathrm{Acq}}$ & $\begin{array}{l}-0.0006^{* * *} \\
(-2.95)\end{array}$ & $\begin{array}{l}-0.0006^{* * *} \\
(-2.97)\end{array}$ & $\begin{array}{l}-0.0006^{* * *} \\
(-2.96)\end{array}$ \\
\hline Stock & $\begin{array}{l}-0.0115^{* * *} \\
(-2.77)\end{array}$ & $\begin{array}{l}-0.0115^{* * *} \\
(-2.78)\end{array}$ & $\begin{array}{l}-0.0115^{* * *} \\
(-2.77)\end{array}$ \\
\hline Ln (Deal Size) & $\begin{array}{l}-0.0019 * * * \\
(-3.98)\end{array}$ & $\begin{array}{l}-0.0019 * * * \\
(-3.98)\end{array}$ & $\begin{array}{l}-0.0019^{* * *} \\
(-3.97)\end{array}$ \\
\hline RelSize $_{\text {Acq }}$ & $\begin{array}{l}0.0194^{* * *} \\
(4.80)\end{array}$ & $\begin{array}{l}0.0195^{* * *} \\
(4.79)\end{array}$ & $\begin{array}{l}0.0195^{* * *} \\
(4.79)\end{array}$ \\
\hline Control transactions & $\begin{array}{l}0.0040 * * * \\
(2.71)\end{array}$ & $\begin{array}{l}0.0040^{* * *} \\
(2.72)\end{array}$ & $\begin{array}{l}0.0040^{* * *} \\
(2.72)\end{array}$ \\
\hline Unlisted $_{\mathrm{Tar}}$ & $\begin{array}{l}0.0031^{* *} \\
(2.15)\end{array}$ & $\begin{array}{l}0.0031^{* *} \\
(2.13)\end{array}$ & $\begin{array}{l}0.0031^{* *} \\
(2.12)\end{array}$ \\
\hline Unlisted $_{\text {Tar }} \times$ Stock & $\begin{array}{l}0.0247^{* * *} \\
(3.55)\end{array}$ & $\begin{array}{l}0.0247^{* * *} \\
(3.55)\end{array}$ & $\begin{array}{l}0.0247^{* * *} \\
(3.55)\end{array}$ \\
\hline IntraBorder & $\begin{array}{l}-0.0002 \\
(-0.18)\end{array}$ & $\begin{array}{l}-0.0002 \\
(-0.18)\end{array}$ & $\begin{array}{l}-0.0002 \\
(-0.19)\end{array}$ \\
\hline Country, industry, and year FE & yes & yes & yes \\
\hline Adj. $\mathrm{R}^{2}$ & 0.0221 & 0.0223 & 0.0223 \\
\hline F-Statistic & 10.12 & 9.29 & 8.72 \\
\hline Observations & 18,494 & 18,494 & 18,494 \\
\hline
\end{tabular}

Note: The table presents the results of ordinary least squares regressions. The dependent variable is the acquirer's announcement 3-day abnormal returns $\left(\mathrm{CAR}_{\mathrm{Acq}}\right)$ around the deal announcement date. Variable definitions are in appendix. All ratio variables are winsorized at 0.01 and 0.99 . Test statistics are calculated based on firm-clustered robust standard errors and statistical significance is denoted by $* * *, * *, *$ for the $1 \%, 5 \%$ and $10 \%$ levels, respectively. For each variable, the t-statistic is reported within brackets below the corresponding coefficient estimate. All specification includes country, industry, and year fixed effects (FE). 
column reports on the baseline specification (i.e., without the interaction variables). Once controlled for firm and deal characteristics, acquirer abnormal returns are not statistically different between family and non-family firms. This appears to be inconsistent with previous literature which reports a positive effect of family ownership on acquirer abnormal returns (see, e.g., Ben-Amar and Andre, 2006; Basu, Dimitrova and Paeglis, 2009; Sraer and Thesmar, 2007; Bouzgarrou and Navatte, 2013).

In column 2, we augment the baseline specification with the variable which interacts bidder leverage with family dummy $\left(\operatorname{Lev}_{\mathrm{Acq}} \times \mathrm{FD}_{\mathrm{Acq}}\right)$. The coefficient estimate of the interaction variable is negative without being statistically significant at conventional levels. This suggests that the leverage ratio does not affect acquirer CARs in family firms. Interestingly, the coefficient estimate of family dummy, which captures the effect of family ownership for a firm with zero debt on acquirer CARs, is positive and statistically significant at the $10 \%$ level in column 2. This indicates that in comparison to non-family firms, family firms with zero debt earn 50 basis points higher abnormal returns. The market reaction associated with $M \& A$ decisions appears to decrease with increasing leverage for family firms, but this effect is statistically insignificant at conventional levels. Most importantly, in column 3, we augment the specification in column 2 by adding the triple interaction variable (CrossIndustry $\times \operatorname{Lev}_{\mathrm{Acq}} \times \mathrm{FD}_{\mathrm{Acq}}$ ) in order to assess whether cross-industry diversifications in family firms are at the expense of minority shareholders or not. Interestingly, the triple interaction variable is not statistically significant. This indicates that family firms with blockholders that value control high are not doing cross-industry M\&A deals at the expense of their minority shareholders.

Our coefficient estimates for control variables in table 7 are largely consistent with prior literature (see Betton, Eckbo and Thorburn (2008) for a review). We find particularly that stock payment, the bidder's market-to-book ratio and deal size are negatively associated with announcement returns, while relative size, the acquisition of private targets (unlisted target), and control transactions are positively associated with bidder abnormal returns.

\section{Conclusions}

Family blockholders that value control high are reluctant to relinquish it and hence prefer non-diluting securities such as debt to fund new investments (Ellul, 2008; Croci, Doukas and Gonenc, 2011). Using 
leverage as a proxy for the family owner's attitude toward control, this study examines the relation between family ownership and acquisition activity.

Relying on a large sample of European M\&A deals announced during the period 1990-2013, we study the determinants of the propensity to undertake cross-industry M\&A transactions. Consistent with previous literature, we first show that family firms do on average less diversifying acquisitions in comparison to non-family firms. However, family firms with high control motives, captured by the firm's leverage ratio, tend to make more cross-industry acquisitions as this allows the family owners to effectively diversify their wealth without reducing their voting power. In addition, we analyze the value effect associated with the firm's M\&A decision. Our result indicates that diversifying acquisitions undertaken by family firms that value control high are not implemented at the expense of minority shareholders.

This study contributes to literature by providing evidence that the attitude toward control in family firms shapes substantially the firm's behavior in the M\&A market. In addition, our result corroborates the implication of Ellul (2008) that high leverage in family firms signals control motives of family blockholders.

Accepted by: P.C. Andreou, PhD, Editor-in-Chief(Pro-Tem), May 2016 
Appendix. Variable definitions

\begin{tabular}{|c|c|}
\hline CrossIndustry & $\begin{array}{l}\text { Dummy variable equal to } 1 \text { if the acquirer and target firm belong } \\
\text { to different industries (at 2-digit SIC code level), and } 0 \\
\text { otherwise. }\end{array}$ \\
\hline CrossIndustryCash & $\begin{array}{l}\text { Dummy variable equal to } 1 \text { if the acquirer and target firm belong } \\
\text { to different industries (at } 2 \text {-digit SIC code level) and if the } \\
\text { acquirer uses mainly cash }(\geq 50 \%) \text { to finance the deal, and } 0 \\
\text { otherwise. }\end{array}$ \\
\hline CAR $[-1 ;+1]$ & $\begin{array}{l}\text { Cumulative abnormal return of the acquirer's stock against the } \\
\text { local market index (from a Beta-one model) over a 3-day event } \\
\text { window around deal announcement (i.e., day 0). }\end{array}$ \\
\hline $\operatorname{Lev}_{\text {Acq }}$ & $\begin{array}{l}\text { Book value of debt (of acquiring firm) / Total assets (of acquiring } \\
\text { firm); source: Worldscope [WC03255/WC02999] (both in local } \\
\text { currency). }\end{array}$ \\
\hline $\mathrm{FD}_{\mathrm{Acq}}$ & $\begin{array}{l}\text { Dummy variable equal to } 1 \text { if the ultimate owner of the acquiring } \\
\text { company represents "one or more named individuals or families" } \\
\text { according to the database Amadeus, and } 0 \text { otherwise (at } 25 \% \\
\text { control threshold level). }\end{array}$ \\
\hline Stock & $\begin{array}{l}\text { Dummy variable equal to } 1 \text { for deals which are purely } \\
\text { stock-financed, and } 0 \text { otherwise. }\end{array}$ \\
\hline $\operatorname{Ln}\left(\mathrm{MV}_{\mathrm{Acq}}\right)$ & $\begin{array}{l}\text { Natural logarithm of the acquirer's equity market value; source: } \\
\text { Worldscope [WC } 07210 \text { for equity market value in U\$]. }\end{array}$ \\
\hline RelSize $_{\text {Acq }}$ & $\begin{array}{l}\text { Deal value divided by equity market value (of the acquiring } \\
\text { firm). Deal value is from SDC Platinum and equity market value } \\
\text { from Worldscope [WC07210] (both in U\$). }\end{array}$ \\
\hline$(\mathrm{M} / \mathrm{B})_{\mathrm{Acq}}$ & $\begin{array}{l}\text { Market value of equity divided by book value of equity (both of } \\
\text { the acquiring firm); source: Worldscope [WC07210/WC07220] } \\
\text { (both in U\$). }\end{array}$ \\
\hline TangAssets $_{\text {Acq }}$ & $\begin{array}{l}\text { Tangible assets divided by total assets (both of the acquiring } \\
\text { firm); source: Worldscope [WC02501/WC02999] (both in local } \\
\text { currency). }\end{array}$ \\
\hline Cash $_{\text {Acq }}$ & $\begin{array}{l}\text { Cash and tradable securities divided by total assets (both of the } \\
\text { acquiring firm); source: Worldscope [WC02001/WC02999] } \\
\text { (both in local currency). }\end{array}$ \\
\hline $\mathrm{ROA}_{\mathrm{Acq}}$ & $\begin{array}{l}\text { EBITDA divided by total assets (both of the acquiring firm); } \\
\text { source: Worldscope [WC18198/WC02999] (both in local } \\
\text { currency). }\end{array}$ \\
\hline SalesGth $_{\text {Acq }}$ & $\begin{array}{l}\text { Yearly growth rate of total sales (of the acquiring firm); source: } \\
\text { Worldscope [WC } 07240 \text { for total sales in U\$]. }\end{array}$ \\
\hline Unlisted $_{\mathrm{Tar}}$ & $\begin{array}{l}\text { Dummy variable equal to } 1 \text { if target firm is not listed, and } 0 \\
\text { otherwise. }\end{array}$ \\
\hline IntraBorder & $\begin{array}{l}\text { Dummy variable equal to } 1 \text { if the bidding and target firm are } \\
\text { headquartered in the same country, and } 0 \text { otherwise. }\end{array}$ \\
\hline DivLevel $_{\text {Acq }}$ & $\begin{array}{l}\text { Number of industries (at 2-digit SIC code level) in which the } \\
\text { acquirer operates as per year-end prior to deal announcement. }\end{array}$ \\
\hline
\end{tabular}


Appendix. (Continued)

\begin{tabular}{|c|c|}
\hline STdebt $_{\text {Acq }}$ & $\begin{array}{l}\text { Book value of short-term debt (of acquiring firm) / Total assets } \\
\text { (of acquiring firm); calculated as the difference between LevAcq } \\
\text { and LTdebt } \\
\text { Acq. }\end{array}$ \\
\hline LTdebt $_{\text {Acq }}$ & $\begin{array}{l}\text { Book value of long-term debt (of acquiring firm) / Total assets } \\
\text { (of acquiring firm); source: Worldscope [WC03251/WC02999] } \\
\text { (both in local currency). }\end{array}$ \\
\hline Control transactions & $\begin{array}{l}\text { Dummy variable equal to } 1 \text { if the transaction provides the } \\
\text { acquirer with a majority stake in the target firm, and } 0 \text { otherwise. }\end{array}$ \\
\hline Ln (Deal Size) & Natural logarithm of the deal size in U\$. \\
\hline
\end{tabular}

\section{References}

Achleitner, A. K.; Kaserer, C.; Kauf, T.; and Volk, S. 2010. DAXplus Family - Ein Aktienindex zur Darstellung der Performance von Familienunternehmen. CEFS Working Paper 2010-05, Technische Universität München.

Adhikari, H. 2013. Family versus non-family firms: Who are better acquirers? Working Paper, University of South Florida.

Aktas, N.; de Bodt, E.; and Roll, R. 2004. Market response to European regulation of business combinations. Journal of Financial and Quantitative Analysis 39(4): 731-757.

Alderson, K. J. 2011. Understanding the Family Business. New York: Business Expert Press.

Alexandridis, G.; Petmezas, D.; and Travlos, N. 2010. Gains from mergers and acquisitions around the world: New evidence. Financial Management 39(4): 1671-1695.

Amihud, Y.; Lev, B.; and Travlos, N. G. 1990. Corporate control and the choice of investment financing: The case of corporate acquisitions. Journal of Finance 45(2): 603-616.

Ampenberger, M.; Schmid, T.; Achleitner, A. K.; and Kaserer, C. 2009. Capital structure decisions in family firms - Empirical evidence from Germany. CEFS-Working Paper 2009-5, Technische Universität München.

Anderson, R. C., and Reeb, D. M. 2003a. Founding-family ownership and firm performance: Evidence from the S\&P 500. Journal of Finance 58(3): 1301-1327.

Anderson, R. C., and Reeb, D. M. 2003b. Founding-family ownership, corporate diversification and firm leverage. Journal of Law and Economics 46(2): 653-680.

Andres, C. 2008. Large shareholders and firm performance - An empirical examination of founding-family ownership. Journal of Corporate Finance 14(4): 431-445. 
Astrachan, J.; Klein, S.; and Smyrnios, K. 2002. The F-PEC scale of family influence: A proposal for solving the family business definition. Family Business Review 15(1): 45-58.

Barclay, M., and Holderness, C. 1989. Private benefits from control of public corporations. Journal of Financial Economics 25(2): 371-396.

Barontini, R., and Caprio, L. 2006. The effect of family control on firm value and performance: Evidence from Continental Europe. European Financial Management 12(5): 689-723.

Basu, N.; Dimitrova, L.; and Paeglis, I. 2009. Family control and dilution in mergers. Journal of Banking and Finance 33(5): 829-841.

Bauguess, S., and Stegemoller, M. 2008. Protective governance choices and the value of acquisition activity. Journal of Corporate Finance 14(5): 550-566.

Becker, G. S. 1981. A Treatise on the Family. Cambridge, MA: Harvard University Press.

Ben-Amar, W., and Andre, P. 2006. Separation of ownership from control and acquiring firm performance: The case of family ownership in Canada. Journal of Business Finance and Accounting 33(3-4): 517-543.

Berle, A., and Means, G. 1932. The Modern Corporation and Private Property. New York, NY: Mac-Millan.

Bertrand, M., and Schoar, A. 2006. The role of family in family firms. Journal of Economic Perspectives 20(2): 73-96.

Betton, S.; Eckbo, B.; and Thorburn, K. 2008. Corporate takeovers. In B. Eckbo (Ed.), Handbook of Corporate Finance: Empirical Corporate Finance, Volume 2 (pp. 291-429). Elsevier/North-Holland, Handbooks in Finance Series.

Bouzgarrou, H., and Navatte, P. 2013. Ownership structure and acquirers performance: Family versus non-family firms. International Review of Financial Analysis 27(3): 123-134.

Brown, S. J., and Warner, J. B. 1980. Measuring security price performance. Journal of Financial Economics 8(3): 205-258.

Brown, S. J., and Warner, J. B. 1985. Using daily stock returns: The case of event studies. Journal of Financial Economics 14(1): 3-31.

Caprio, L.; Croci, E.; and Del Giudice, A. 2011. Ownership structure, family control, and acquisition decisions. Journal of Corporate Finance 17(5): 1636-1657.

Casson, M. 1999. The economics of the family firm. Scandinavian Economic History Review 47(1): 10-23.

Chami, R. 1999. What's different about family business? Working Paper, University of Notre Dame and the International Monetary Fund.

Chrisman, J., Chua, J., and Steier, L. 2003. An introduction to theories of family business. Journal of Business Venturing 18(4): 441-448.

Claessens, S.; Djankov, S.; Fan, J. P.; and Lang, L. H. 2002. Disentangling the incentive and entrenchment effects of large shareholdings. Journal of Finance 57(6): 2741-2771. 
Croci, E.; Doukas, J.; and Gonenc, H. 2011. Family control and financing decisions. European Financial Management 17(5): 860-897.

DeAngelo, H., and DeAngelo, L. 2000. Controlling stockholders and the disciplinary role of corporate payout policy: A study of the Times Mirror Company. Journal of Financial Economics 56(2): 153-207.

Demsetz, H., and Lehn, K. 1985. The structure of corporate ownership: Causes and consequences. Journal of Political Economy 93(6): 1155-1177.

Dyer, W. G. 2006. Examining the family effect on firm performance. Family Business Review 19(4): 253-273.

Ellul, A. 2008. Control motivations and capital structure decisions. Working Paper, Kelley School of Business, Indiana University.

Faccio, M., and Lang, L. 2002. The ultimate ownership of Western European corporations. Journal of Financial Economics 65(3): 365-395.

Faccio, M., and Masulis, R. W. 2005. The choice of payment method in European mergers and acquisitions. Journal of Finance 60(3): 1345-1388.

Faccio, M.; Marchica, M. T.; and Mura, R. 2011. Large shareholder diversification and corporate risk-taking. Review of Financial Studies 24(11): 3601-3641.

Fahlenbrach, R. 2009. Founder CEOs, investment decisions, and stock market performance. Journal of Financial and Quantitative Analysis 44(2): 439-466.

Fama, E., and Jensen, M. 1985. Organizational forms and investment decisions. Journal of Financial Economics 14(1): 101-119.

Franks, J.; Mayer, C.; Volpin, P.; and Wagner, H. F. 2012. The life cycle of family ownership: International evidence. Review of Financial Studies 25(6): 1675-1712.

Ghosh, A., and Ruland, W. 1998. Managerial ownership, the method of payment for acquisitions, and executive job retention. Journal of Finance 53(2): 785-798.

Harris, M., and Raviv, A. 1988. Corporate control contests and capital structure. Journal of Financial Economics 20(1-2): 55-86.

Herger, N., and McCorriston, S. 2014. Horizontal, vertical, and conglomerate FDI: Evidence from cross border acquisitions. Working Paper 14/02, Study Center Gerzensee.

Holderness, C. G. 2009. The myth of diffuse ownership in the United States. Review of Financial Studies 22(4): 1377-1408.

Holmen, M., and Nivorozhkin, E. 2007. The impact of family ownership and dual class shares on takeover risk. Applied Financial Economics 17(10): 785-804.

Israel, R. 1991. Capital structure and the market for corporate control: The defensive role of debt financing. Journal of Finance 46(4): 1391-1409.

James, H. 1999. Owner as manager, extended horizons and the family firm. International Journal of the Economics of Business 6(1): 41-56.

Jaskiewicz, P. 2006. Performance-Studie börsennotierter 
Familienunternehmen. Lohmar, Germany: EUL Verlag.

Jensen, M. C., and Meckling, W. H. 1976. Theory of the firm: Managerial behavior, agency costs and ownership structure. Journal of Financial Economics 3(4): 305-360.

Klasa, S. 2007. Why do controlling families of public firms sell their remaining ownership stake? Journal of Financial and Quantitative Analysis 42(2): 339-368.

Klein, S. 2000. Family businesses in Germany - significance and structure. Family Business Review 13(3): 157-183.

Klein, S. 2004. Familienunternehmen. Wiesbaden: Gabler-Verlag. La Porta, R.; Lopez-de-Silanes, F.; and Shleifer, A. 1999. Corporate ownership around the world. Journal of Finance 54(2): 471-517.

Lins, K. V.; Volpin, P.; and Wagner, H. F. 2013. Does family control matter? International evidence from the 2008-2009 financial crisis. Review of Financial Studies 26(10): 2583-2619.

Martin, K. J. 1996. The method of payment in corporate acquisitions, investment opportunities, and management ownership. Journal of Finance 51(4): 1227-1246.

Masulis, R. W.; Pham, P. K.; and Zein, J. 2011. Family business groups around the world: Financing advantages, control motivations, and organizational choices. Review of Financial Studies 24(11): 3556-3600.

Maury, B. 2006. Family ownership and firm performance: Empirical evidence from Western European corporations. Journal of Corporate Finance 12(2): 321-341.

May, D. O. 1995. Do managerial motives influence firm risk reduction strategies? Journal of Finance 50(4): 1291-1308.

McConaughy, D.; Matthews, C.; and Fialko, A. 2001. Founding family controlled firms - Performance, risk and value. Journal of Small Business Management 39(1): 31-49.

Miller, D.; Le Breton-Miller, I.; and Lester, R. H. 2010. Family ownership and acquisition behavior in publicly-traded companies. Strategic Management Journal 31(2): 201-223.

Miller, D.; Le Breton-Miller, I.; Lester, R. H.; and Cannella Jr., A. A. 2007. Are

family firms really superior performers? Journal of Corporate Finance 13(5): 829-858.

Morck, R. K., and Yeung, B. 2003. Agency problems in large family business groups. Entrepreneurship Theory and Practice 27(4): 367-382.

Song, S. I.; Ali, R.; and Pillay, S. 2008. Effects of take-over motives and ownership structure on premiums paid: Evidence from Malaysia. International Journal of Business and Management 3(6): 75-88.

Sraer, D., and Thesmar, D. 2007. Performance and behavior of family firms: Evidence from the French stock market. Journal of the European Economic Association 5(4): 709-751.

Stulz, R. M. 1988. Managerial control of voting rights. Journal of Financial 
Economics 20(1-2): 25-54.

The Economist. 2006. All in the Family - Bertelsmann saves itself from a public listing. May 27th 2006 issue: 62 .

Tsoutsoura, M. 2015. The effect of succession taxes on family firm investment: Evidence from a natural experiment. Journal of Finance 70(2): 649-688.

Villalonga, B., and Amit, R. 2006. How do family ownership, control and management affect firm value? Journal of Financial Economics 80(2): 385-417.

Zhou, Y. M.; Li, X.; and Svejnar, J. 2011. Subsidiary divestiture and acquisition in a financial crisis: Operational focus, financial constraints, and ownership. Journal of Corporate Finance 17(2): 272-287. 